\title{
"Late glacial and Holocene palaeohydrology in the western Mediterranean region: the Lake Estanya record (NE Spain)"
}

\author{
Mario Morellón ${ }^{1 *}$, Blas Valero-Garcés ${ }^{1}$, Teresa Vegas-Vilarrúbia ${ }^{2}$, Penélope \\ González-Sampériz ${ }^{1}$, Óscar Romero ${ }^{3}$, Antonio Delgado-Huertas ${ }^{4}$, Pilar Mata ${ }^{5}$, Ana \\ Moreno $^{1,6}$, Mayte Rico ${ }^{1}$, Juan Pablo Corella ${ }^{1}$
}

${ }^{1}$ Departamento de Procesos Geoambientales y Cambio Global. Instituto Pirenaico de Ecología (IPE) - CSIC. Campus de Aula Dei. Avda Montañana 1005. 50059 Zaragoza, Spain. Phone: +34 976716142. Fax: +34976716019

${ }^{2}$ Departamento de Ecología. Facultad de Biología, Universidad de Barcelona.

Av. Diagonal 645, Edf. Ramón Margalef. 08028 Barcelona, Spain.

${ }^{3}$ Instituto Andaluz de Ciencias de la Tierra (IACT)-CSIC. Facultad de Ciencias, Universidad de Granada. Campus Fuentenueva. 18002 Granada, Spain.

${ }^{4}$ Estación Experimental del Zaidín (EEZ) - CSIC, Prof. Albareda 1, 18008 Granada, Spain.

${ }^{5}$ Facultad de Ciencias del Mar y Ambientales, Universidad de Cádiz. Polígono Río San Pedro s/n. 11510 Puerto Real (Cádiz), Spain.

${ }^{6}$ Limnological Research Center (LRC). Department of Geology and Geophysics, University of Minnesota. 220 Pillsbury Hall / 310 Pillsbury Drive S.E. MN 55455-0219 Minneapolis, USA.

*Corresponding author. E-mail address: mariomm@ipe.csic.es 


\section{ABSTRACT}

The multi-proxy analysis of sediment cores recovered in karstic Lake Estanya $\left(42^{\circ} 02^{\prime} \mathrm{N}, 0^{\circ} 32^{\prime} \mathrm{E} ; 670 \mathrm{~m}\right.$ a. s. $1 .$, NE Spain), located in the transitional area between the humid Pyrenees and the semi-arid Central Ebro Basin, provides the first high-resolution, continuous sedimentary record in the region, extending back the last 21000 years. The integration of sedimentary facies, elemental and isotopical geochemistry and biogenic silica, together with a robust age model based on 17 AMS radiocarbon dates, enables precise reconstruction of the main hydrological and environmental changes in the region during the last deglaciation.

Arid conditions, represented by shallow lake levels, predominantly saline waters and reduced organic productivity occurred throughout the Last Glacial Maximum (21 18 cal kyrs BP) and the late glacial, reaching their maximum intensity during the period 18 - 14.5 cal kyrs BP (including Heinrich event 1) and the Younger Dryas (12.9 - 11.6 cal kyrs BP). Less saline conditions characterized the 14.5 - 12.6 cal kyrs BP period, suggesting higher effective moisture during the Bölling/Allerød. The onset of more humid conditions started at 9.4 cal kyrs, indicating a delayed hydrological response to the onset of the Holocene which is also documented in several sites of the Mediterranean Basin. Higher, although fluctuating, Holocene lake levels were punctuated by a mid Holocene arid period between 4.8 and 4.0 cal kyrs BP. A major lake-level rise occurred at $1.2 \mathrm{cal}$ kyrs BP, conducive to the establishment of conditions similar to the present and interrupted by a last major water level drop, occurring around 800 cal yrs BP, which coincides with the Medieval Climate Anomaly.

The main hydrological stages in Lake Estanya are in phase with most Western Mediterranean and North Atlantic continental and marine records, but our results also show similarities with other Iberian and northern African reconstructions, emphasizing 
peculiarities of palaeohydrological evolution of the Iberian Peninsula during the last deglaciation. 


\section{INTRODUCTION}

North Atlantic responses to global climate change during the last glacial cycle have been widely documented (e.g., Chapman et al., 2000) although information about the timing, intensity and effects of these climatic fluctuations in continental areas of Europe is comparatively more scarce than in marine regions. Reconstructing the environmental and hydrological response to millennial scale fluctuations of midlatitude, climate-sensitive areas, such as the Mediterranean basin, is crucial to understand climate connections between high and low latitudes (Moreno et al., 2005; Tzedakis, 2007). Several marine reconstructions have shown strong and synchronous responses to the west of the Iberian Peninsula (de Abreu et al., 2003; Martrat et al., 2007; Naughton et al., 2007), in the southwestern Mediterranean Sea (Beaudouin et al., 2005; Beaudouin et al., 2007; Frigola et al., 2007; Frigola et al., 2008) and the Alboran Sea (Cacho et al., 2001; Combourieu Nebout et al., 2002; Martrat et al., 2004; Moreno et al., 2005). Marine-based pollen records have also provided evidence of the rapid response of terrestrial vegetation to these climate fluctuations during last glacial and interglacial cycles (Sánchez Goñi et al., 1999; Boessenkool et al., 2001; Roucoux et al., 2001; Sánchez-Goñi et al., 2002; Roucoux et al., 2005; Naughton et al., 2007; Fletcher and Sánchez Goñi, 2008).

Although long Iberian terrestrial records have generally shown a broadly similar pattern during late glacial and Holocene times: e.g., Padul Peatbog (Pons and Reille, 1988); Lake Banyoles (Pérez-Obiol and Julià, 1994; Wansard, 1996); Laguna Roya (Allen et al., 1996); Lake Siles (Carrión, 2002); etc., most of them are pollen-based reconstructions, lacking the multi-proxy data necessary to reconstruct effective moisture and hydrological changes precisely, which are particularly significant in the Mediterranean Basin during deglaciation and the Holocene (Magny and Bégeot, 2004; 
Tzedakis, 2007). Furthermore, only a few of the available multidisciplinary studies of Iberian continental sequences have the robust chronological control necessary to identify short-term climatic fluctuations: e.g., the new Padul sequence (Ortiz et al., 2004); El Portalet peatbog (González-Sampériz et al., 2006); Lake Redó (Pla and Catalán, 2005); or Lake Enol (Moreno et al., in press). In addition, most of these sites are located in mountainous regions of the Iberian Peninsula, and the hydrological amplitude and the character of environmental change in low-lying areas is still poorly understood: e.g., the Laguna Medina record (Reed et al., 2001); or Lake Zoñar (MartínPuertas et al., 2008).

In spite of the ability of Atmospheric General Circulation Models (AGCMs) to simulate large-scale changes, they usually tend to underestimate hydrological fluctuations (Kohfeld and Harrison, 2000; Jansen et al., 2007). Recent simulation attempts have failed to reconstruct moisture changes in southern Europe; there is a significant mismatch between observed patterns (e.g., Global Lake Status Data Base (GLSDB) (Qin et al., 1998); BIOME project (Prentice and Webb, 1998)) and simulated climates (Kohfeld and Harrison, 2000). Besides, the hydrological response of the Western Mediterranean region to global climate fluctuations, such as the Last Glacial Maximum; the Younger Dryas and the Bölling/Allerød (Greenland stadial 1 (GS-1) and interstadial 2 (GI-2), respectively, Hoek et al., 2008) or the internal structure of the Early Holocene climate amelioration, are still unclear (Tzedakis, 2007). In the Iberian Peninsula, the complex topography and the interplay of Atlantic and Mediterranean influences (Harrison et al., 1996) limit the AGCMs reliability. In fact, marked differences between western (e.g., Allen et al., 1996) and eastern (e.g., Carrión and Dupré, 1996) climate reconstructions based on Iberian records have been documented. Although a strong climatic linkage with the North Atlantic has been demonstrated, some 
records have also shown a synchrony of arid events with the North African domain (Reed et al., 2001).

In order to clarify these uncertainties, new long continuous records with adequate chronological control are needed. In particular, closed lake basins located in the semi-arid regions of mid-latitudes can provide useful proxy climate data in order to improve the available models (Qin et al., 1998). In northeastern Spain, most of the environmental reconstructions have been carried out in the high altitudes of the Pyrenees (Jalut et al., 1992; Montserrat-Martí, 1992; Pla and Catalán, 2005; GonzálezSampériz et al., 2006) and the Iberian Range (Stevenson, 2000; Moreno et al., 2008; Valero Garcés et al., 2008). The only available data for the low-land areas of the Central Ebro Basin are based on the study of archaeological sites (González-Sampériz, 2004; Ferrio et al., 2006), slope (Gutiérrez-Elorza and Peña-Monné, 1998; Gutiérrez, 2006) and alluvial deposits (Rico, 2004; Sancho et al., 2007) or playa lake records (Davis, 1994; Schutt, 1998; Valero-Garcés et al., 2000b; Valero-Garcés et al., 2004; GonzálezSampériz et al., 2005; Davis and Stevenson, 2007; Luzón et al., 2007; GonzálezSampériz et al., 2008), which often lack a detailed chronology and are affected by the presence of hiati.

The transitional area between the sub-humid Pyrenees and the semi-arid Central Ebro Basin, a climatically sensitive region characterized by a strong hydrological gradient (Cuadrat et al., 2008), is of special interest for the reconstruction of past environmental and climate change. In this paper, we provide a multi-proxy reconstruction of the palaeohydrological evolution of Estanya Lake during the last $21,000 \mathrm{yr}$ which focuses on sedimentological and geochemical evidence from sediment cores. Previous research carried out at this site (Riera et al., 2004; Riera et al., 2006; Morellón et al., 2008; Morellón et al., 2009) has shown the potential of this sequence as 
a continuous archive of regional past hydrological fluctuations during the last millennia. We also present an improved, robust chronological model which builds on the previous set of dates published in Morellón et al. (2008). This model is based on 12 new chronological dates and includes a reservoir correction. The Lake Estanya sedimentary sequence constitutes a continuous record that provides an insight into the timing and amplitude of millennial to centennial scale hydrological changes experienced in the area since the LGM.

\section{REGIONAL SETTING}

\subsection{Geological and geomorphological setting}

'Balsas de Estanya' $\left(42^{\circ} 02^{\prime} \mathrm{N}, 0^{\circ} 32^{\prime} \mathrm{E} ; 670 \mathrm{~m}\right.$. a. s. 1.) is a karstic lake complex located at the southern foothills of the External Pyrenean Ranges in northeastern Spain (Fig. 1). These mountain ranges are mainly composed of Mesozoic formations with EW trending folds and thrusts (Martínez-Peña and Pocoví, 1984). Karstic processes affecting Upper Triassic carbonate and evaporite materials outcropping along these structures have led to the development of large poljes and dolines (IGME, 1982). The Balsas de Estanya lake complex constitutes a relatively small endorheic basin of 2.45 $\mathrm{km}^{2}$ (López-Vicente, 2007) (Fig. 1B) that belongs to a larger Miocene polje (SanchoMarcén, 1988). Lake basin substrate is formed by Upper Triassic low-permeability marls and claystones (Keuper facies), whereas Mid Triassic limestones and dolostones (Muschelkalk facies) make up the higher relief of the catchment (Sancho-Marcén, 1988). The karstic system consists of two dolines with water depths of $7 \mathrm{~m}$ and $20 \mathrm{~m}$, and a seasonally flooded one (Fig. 1B). Several other sediment-filled karstic depressions also occur in the area (IGME, 1982).

\subsection{Climate and vegetation}


The region has a Mediterranean continental climate with a long summer drought (León-Llamazares, 1991). Mean annual temperature is $14{ }^{\circ} \mathrm{C}$ ranging from $4{ }^{\circ} \mathrm{C}$ (January) to $24^{\circ} \mathrm{C}$ (July). Mean annual rainfall is $470 \mathrm{~mm}$ and mean rainfall for the driest and most humid months are $18 \mathrm{~mm}$ (July) and $50 \mathrm{~mm}$ (October), respectively (Meteorological Station at Santa Ana Reservoir, $17 \mathrm{~km}$ southeast of the lake). Most of the precipitation is related to Atlantic fronts during the winter months, although mesoscale convective systems produce some precipitation during the summer (GarcíaHerrera et al., 2005).

The Estanya lakes are located at 670 m. a. s. 1. at the boundary between the Quercus rotundifolia and the Quercus faginea forest formations that corresponds to the transitional zone between the Mediterranean and Submediterranean bioclimatic regimes (Blanco-Castro et al., 1997) (Fig. 1A). The present-day landscape is a mosaic of natural vegetation alternating with patches of cereal crops. Hygrophyte communities with Phragmites sp., Juncus sp., Typha sp., and Scirpus sp., are developed in the littoral zones of the lakes.

\subsection{Lake hydrology and limnology}

The main lake basin, 'Estanque Grande de Abajo' is composed of two sub-basins with steep margins and maximum water depths of 12 and $20 \mathrm{~m}$, separated by a sill, 2-3 m below present-day lake level (Fig. 1C), which only emerges during long dry periods (Morellón et al., 2008), suggesting a dynamic of alternating connection and isolation of the two basins over time. Maximum and minimum lengths are $850 \mathrm{~m}$ and $340 \mathrm{~m}$, respectively, and total lake surface is $188306 \mathrm{~m}^{2}$. Lake volume has been calculated as $983728 \mathrm{~m}^{3}$ (Ávila et al., 1984). The 'Estanque Grande de Abajo' has a relatively small watershed (surface area $=106.50 \mathrm{Ha}$ ) (López-Vicente, 2007). Although there is no 
permanent inlet, several ephemeral creeks drain the catchment, providing clastic material to the lake (López-Vicente, 2007).

Archaeological evidence indicates water management in the area since the $12^{\text {th }}$ century (Riera et al., 2004; Riera et al., 2006). An artificial canal, partially collapsed, connects the small lake 'Estanque Grande de Arriba' with the main lake. However, given the negligible water volume provided by this canal, it is disregarded as a significant input to the lake. There is no surface outlet, and the lake basin substrate, composed of low permeability Upper Triassic Keuper facies, limits groundwater losses. Thus, the modern hydrological balance of Lake Estanya is mainly controlled by groundwater inputs and evaporation output. Estimated evapotranspiration (Meteorological Station at Santa Ana Reservoir) is $774 \mathrm{~mm} \mathrm{yr}^{-1}$, exceeding rainfall by about $300 \mathrm{~mm} \mathrm{yr}^{-1}$. Consequently, the lake is mainly fed by groundwaters from the surrounding local dolostone aquifer, which is probably connected to the hydrogeological system of the Estopiñán Syncline (Villa and Gracia, 2004).

Groundwaters are dilute (electrical conductivity (EC), $630 \mu \mathrm{S} / \mathrm{cm}$ and total dissolved solids (TDS), $350 \mathrm{mg} / \mathrm{l}$ ) carbonate and sulphate-rich, while lake water is brackish (EC, $3200 \mu \mathrm{S}$ and TDS, $3400 \mathrm{mg} / \mathrm{l})$, sulphate and calcium - rich, indicating a long residence time and a high influence of evaporation in the system. The lake is monomictic, with thermal stratification and anoxic hypolimnetic conditions during spring and summer (Table 1) and oligotrophic (Ávila et al., 1984). Diatoms are dominated by the genus Cyclotella and proliferate in the mixing season, until the beginning of summer stratification season (Ávila et al., 1984). Although the presence of Chara sp. and aquatic macrophytes, such as Ranunculaceae, Potamogeton or Myriophyllum has been reported, the development of these communities is limited by the steep margins of the lake (Cambra, 1991). 


\section{MATERIALS AND METHODS}

The Lake Estanya watershed was mapped using topographic and geological maps and aerial photographs. Coring operations were conducted in two phases: four cores were retrieved in 2004 using a modified Kullenberg piston coring equipment and platform from the Limnological Research Center (LRC), University of Minnesota, and an additional $\mathrm{Uwitec}^{\circledR}$ core was recovered in 2006. The deepest sites (1A and 5A) (Fig. 1C) reached $4.5 \mathrm{~m}$ and $11 \mathrm{~m}$ below the lake floor, respectively. The uppermost part of the sequence was reconstructed using a short core $(0 \mathrm{~A})$, recovered from closely adjacent to sites $1 \mathrm{~A}$ and $5 \mathrm{~A}$ (Fig. 1C). Physical properties (magnetic susceptibility and density) were measured using a Geotek Multi-Sensor Core Logger (MSCL) every $1 \mathrm{~cm}$. The cores were subsequently split in two halves and imaged with a DMT Core Scanner and a GEOSCAN II digital camera. Sedimentary facies were defined following LRC procedures (Schnurrenberger et al., 2003).

An X-Ray Fluorescence (XRF) core scanner was applied to the longest core sequences (1A and 5A). XRF data used in this study were produced by the newgeneration AVAATECH XRF II core scanner at the University of Bremen using an Xray current of $0.5 \mathrm{~mA}$, at $60 \mathrm{~s}$ count time and $10 \mathrm{kV}$ X-ray voltage. The core archive halves were measured with $5 \mathrm{~mm}$ resolution for light elements (Al, Si, P, S, K, Ca, Ti, Mn and Fe). Consistent with techniques used by Richter et al. (2006), the data obtained by the XRF core scanner were expressed as element intensities. Statistical treatment of XRF data was carried out using the SPSS 14.0 software. Additionally, the geochemistry of 28 sediment samples, representative of different stratigraphic units was analyzed using an Inductively Coupled Plasma-Optical Emission Spectrometry (ICP-OES, JY 98) at the EEAD-CSIC laboratory (Spain). 
Cores were sub-sampled every $2 \mathrm{~cm}$ for Total Organic Carbon (TOC), Total Inorganic Carbon (TIC) and Total Nitrogen (TN); every $5 \mathrm{~cm}$ for mineralogical analyses and $\delta^{13} \mathrm{C}$ in organic matter; every $10 \mathrm{~cm}$ for diatoms and pollen; and every $5 \mathrm{~cm}$ (core 1A) and $10 \mathrm{~cm}($ core $5 \mathrm{~A}$ ) for biogenic silica (Bio $\mathrm{Si}$ ) analysis. TOC and TIC were measured in a LECO SC144 DR furnace. TN was measured by a VARIO MAX CN elemental analyzer. Whole sediment mineralogy was characterized by X-ray diffraction with a Philips PW1820 diffractometer and relative mineral abundance was determined using peak intensity following the procedures described in Chung (1974a and b). Stable carbon isotope composition of organic matter was analyzed by mass spectrometry following standard procedures and using an IRMS Finnigan MAT 251. After carbonate removal by acidification with $\mathrm{HCl} 1: 1, \delta^{13} \mathrm{C}_{\mathrm{org}}$ was measured by an Elemental Analyzer Fison NA1500 NC. Certified standards and replicated samples were routinely measured with satisfactory results, being of an analytical precision better than $0.1 \%$. The isotopic values are reported in the conventional delta notation relative to the PDB standard. Bio Si content was analysed following an automated leaching sequential method (De Master, 1981), modified by Müller and Schneider (1993).

Diatom samples were prepared using the methodology described in Abrantes et al. (2005). Diatom valve abundance (VA) was evaluated based on the number of valves observed per microscope field of view as a semi-quantitative approach. VA was recorded as follows: $5=$ high $(\geq 10$ valves per field of view), $4=$ common $(3-9$ valves per field of view), $3=$ low (1-2 valve(s) per field of view), $2=$ rare $(1$ valve in 2-30 fields of view), $1=$ trace (very rare fragments present) and $0=$ barren (no diatom valves or fragment present). Preliminary determinations of the predominantly benthic or planktonic ecology of diatoms were also carried out. 
The chronology for the lake sequence is constrained by 21 accelerator mass spectrometry (AMS) ${ }^{14} \mathrm{C}$ dates analyzed at the Poznan Radiocarbon Laboratory (Poland) (Tables 2 and 3). Most of the dates are derived from terrestrial macro-remains, but eight bulk organic matter samples were also analyzed due to the scarcity of organic remains at some core intervals. Radiocarbon dates were calibrated using CALPAL_A software (Weninger and Jöris, 2004) and the INTCAL04 curve (Reimer et al., 2004) selecting the median of the $95.4 \%$ distribution ( $2 \sigma$ probability interval). The age/depth relationship was obtained by means of a generalized mixed-effect regression (Heegaard et al., 2005).

\section{RESULTS}

\subsection{The sedimentary sequence}

Correlation between the cores was based on lithology, magnetic susceptibility and density core logs (Fig. 2A). The $10 \mathrm{~m}$ long composite sequence for Lake Estanya has been constructed with cores $1 \mathrm{~A}$ and $5 \mathrm{~A}$, and short core $(0 \mathrm{~A})$ for the uppermost part of the sequence, correlated with 1A using organic matter and carbonate values (Fig. 2B).

Ten facies and seven sedimentary units were defined and correlated within the five sediment cores recovered at the offshore, distal areas of the two Lake Estanya subbasins (Morellón et al., 2009). Reconstruction of depositional subenvironments for each facies has enabled estimation of relative lake level changes (Table 4, Fig. 3).

Preliminary estimates of the relative content on diatoms are coherent with the paleoenvironmental conditions reconstructed for each unit, and strengthen some of the paleohydrological interpretations (Fig. 3). For example, moderate lake level conditions during units VII and VI are also supported by relatively high diatom valve abundance (VA). The main hydrological changes during the lower part of the sequence, indicated by the facies associations are also reflected by qualitative diatom changes: i) planktonic 
diatoms dominated in carbonate-rich facies 7 (units VII and V) and laminated gypsum facies (base of unit VI); ii) the lake level decreases at the top of units VI and V are also marked by an increase in benthic taxa and relatively low VA. Diatoms are nearly absent in sedimentary unit IV, providing another line of evidence for ephemeral lake level conditions at that time. The main sedimentological changes during the transition to unit III are also well marked by qualitative changes in diatom assemblages. At the base of unit III a large increase in VA took place. In Unit I, a gradual increase of VA and dominant planktonic diatoms indicate higher lake levels.

\subsection{Geochemistry}

\subsubsection{Elemental Geochemistry}

The results provided by the XRF Core Scanner are given in Figure 4A. The uppermost $69 \mathrm{~cm}$ of the sediment sequence could not be analyzed due to the poor quality of core surface preservation. Given their low values and noisy character, $\mathrm{P}$ and Mn were not taken into account for the analyses. Comparison with results obtained for key elements in ICP-MS (K, Ca, Fe) and in LECO analyzer (S), has shown significant correlation in all the cases (Fig. 4B), thus supporting the reliability of the measurements. The downcore profiles of light elements correspond clearly with the facies distribution, defined on the basis of sedimentological and compositional analyses (Figs. 3 and 4): i) Si, Al, K, Ti and Fe, with variable, but predominantly higher values in clastic dominated - intervals; ii) S associated with the presence of gypsum-rich facies; and iii) $\mathrm{Ca}$, which displays maximum values in gypsum-rich and carbonate-rich facies. The first group of elements shows the highest values within unit I and along clasticdominated subunits II.2, III.2, III.4 and IV.1, lower values in units V and VI, and higher but variable values in unit VII. Inversely, S values are low in these intervals and higher, but variable in subunit II.1, most of unit III, subunit IV.II and units V and VI. Finally, 
Ca shows a more complex behaviour, as a result of its different sources (endogenic and detrital carbonates derived from the watershed and reworked littoral sediments, and gypsum) (Figs. 3 and 4). Calcium values are generally higher in the lower half of the record, where carbonate-rich and gypsum-rich facies are dominant (units VII, VI, V and IV), and lower, although variable in the clastic and organic- dominated upper units (units III, II and I).

\section{Principal Component Analysis (PCA)}

Principal Component Analysis (PCA) was carried out using this elemental dataset (7 variables and 1289 cases). The first two eigenvectors of PCA account for $88.09 \%$ of the total variance (Table 5A). The first eigenvector represented $66.73 \%$ of the total variance, and displays high positive scores for $\mathrm{Al}, \mathrm{Si}, \mathrm{K}$ and Ti (Table 5B, Fig. 5). The second eigenvector accounts for $21.36 \%$ of the total variance, and it is characterized by high negative scores for $\mathrm{Ca}$ and, to a lesser extent, $\mathrm{S}$, and high positive scores for Fe at the positive end (Table 5B, Fig. 5). The other eigenvectors defined by the PCA analysis (5) were not taken into account to interpret the geochemical variability, given that they explained low percentages of the total variance $(<15 \%)$ (Table 5A).

The PCA analysis supports the inferences: (i) that Al, Si, K, Ti and Fe have a common origin, probably related to their occurrence in silicates and (ii) that $\mathrm{Ca}$ and $\mathrm{S}$ display a similar behaviour, due to their presence in carbonates and gypsum. The Fe contributes to both of the two first eigenvectors and it shows a complex pattern (Table 5B, Fig. 5), likely due to the influence of redox conditions in its deposition (Mackereth, 1966; Tracey et al., 1996; Schaller et al., 1997; Cohen, 2003) and its presence in other minerals (e.g., oxides) apart from silicates. Thus, eigenvector 1 represents clastic input and eigenvector 2 represents carbonate and sulphate deposition. Although clastic 
carbonates also occur, the eigenvector 2 is mostly dominated by gypsum and carbonate endogenic formation and, consequently, can be interpreted as water salinity.

Following Giralt et al. (2008) and Muller et al. (2008) (among others), the location of every sample with respect to the new vectorial space defined by the two first PCA axes and their plot with respect to their composite depth allow us to qualitatively reconstruct the evolution of clastic input and water salinity along the sequence. Positive eigenvector 1 scores represent higher clastic input and characterize intervals in the midupper part of the sequence, dominated by clastic facies (1,2 and 3) and carbonate-rich facies 6 , whose mineralogical content also accounts for a considerable percentage (60 to 75\%) in silicates (Fig. 4). In contrast, negative eigenvector 2 scores indicate higher salinity and characterize the lowermost part of the sequence (units V, VI and VII), dominated by gypsum-rich and carbonate-rich facies; whereas higher but highly variable values are recorded at the mid and upper part of the record.

\subsubsection{Organic geochemistry and stable isotopes}

TOC, TN and atomic TOC/TN ratio

The TOC content of the Lake Estanya sequence averages $4 \%$ but is highly variable, oscillating from $2.8 \%$ (clastic facies) to $6.6 \%$ (organic-rich facies) and, reaching maximum values of up to $20 \%$ at some intervals (Fig. 3). Organic content of Units VII to IV (956.6 to $409.5 \mathrm{~cm}$ ) is relatively low, averaging $2.3 \%$. Units II and III show the highest variability of TOC values. Decimetre-thick intervals dominated by the development of sapropels microbial mats and benthic diatoms (facies 4 and 5, subunits III.1, III.3, III.5 and III.7) characterized by highest TOC values, reaching up to $20 \%$ in some cases, alternate here with clastic dominant intervals (facies 1, 2 and 3, subunits II.2, III.2 and III.4) with relatively low values (0-5\% range). In contrast, TOC values 
remain low and constant within unit I, peaking up to $5 \%$ in some levels with plantdebris laminae.

Total Nitrogen $(\mathrm{TN})$ values, ranging from 0 to $2 \%$, parallel the TOC curve, leading to predominantly constant values of the atomic TOC/TN ratio, centered around 13 (Fig. 3). Typical values for algae are below 10, whereas vascular plants are characterized by ratios higher than 20 (Meyers and Lallier-Vergès, 1999). Thus, the organic matter present in Lake Estanya sediments is predominantly of lacustrine origin with a minor but significant influence of terrestrial plant remains derived from the catchment. However, a slight decreasing upward trend can be observed, changing from values around 15 (units VI to IV) to 11 (unit I), probably reflecting a progressive decrease in the influence of land-derived organic matter (Meyers and Lallier-Vergès, 1999), coherent with sedimentary facies evolution. Additionally, several peaks up to 30 and even 40 appear associated to clastic-rich intervals with plant debris derived from the catchment (Fig. 3).

\section{$\delta^{13} C$ in organic matter}

Organic matter $\delta^{13} \mathrm{C}$ values range from -20 to $-35 \%$. Highest values (-20 to 25 \%) occur in the lower sequence $(536-955 \mathrm{~cm}$ core depth, units VII to V), leading to generally more highly negative but variable values ( -30 to $-35 \%$ ) from unit IV and III (536 - $175 \mathrm{~cm}$ core depth) with significant shifts within units II and unit I (Fig. 3). Given that atomic TOC/TN ratio values are generally constant throughout the sediment sequence and do not match changes in $\delta^{13} \mathrm{C}_{\mathrm{org}}$, isotopic fluctuations must be interpreted mostly as changes in lake productivity and trophic status rather than as changes in organic matter sources (Meyers and Teranes, 2001). Isotopically $\delta^{13} \mathrm{C}_{\text {org }}$ enriched values (-25 to $-20 \%$ ) occurring through the lower to mid part of the sequence (units VIII to IV), are heavier than expected for lacustrine algae (Meyers and Lallier-Vergès, 1999), 
and correlate with intervals characterized by low organic matter content, dominant gypsum and carbonate-rich facies over clastic facies and geochemically more saline conditions (Fig. 4). Lower algal bioproductivity could be a significant factor, however an increase in alkalinity has been proposed to explain $\delta^{13} \mathrm{C}_{\text {org }}$ enrichments in lakes not influenced by land-derived organic matter or algal productivity (Brenner et al., 1999). Reduced availability of dissolved atmospheric $\mathrm{CO}_{2}\left(\delta^{13} \mathrm{C} \sim 7 \%\right.$ ) caused by high alkalinity waters in saline, shallow conditions drives algae towards the incorporation of heavier carbon derived from $\mathrm{HCO}_{3}^{-}$(Keeley and Sandquist, 1992) and thus leading towards isotopically $\delta^{13} \mathrm{C}_{\mathrm{org}}$ enriched organic matter in sediments.

In contrast, more $\delta^{13} \mathrm{C}_{\text {org }}$ depleted values occurring in the uppermost $410 \mathrm{~cm}$ with higher TOC in an inferred deeper lacustrine phase point to enhanced lacustrine algae productivity. Intervals within units III and II with higher TOC generally correspond to more $\delta^{13} \mathrm{C}_{\text {org }}$ depleted values. The uppermost unit $\mathrm{I}$ is characterized by lower TOC values, but slightly higher $\delta^{13} \mathrm{C}_{\text {org }}$ isotopic values similar to those of clastic intervals in unit III. This reduction in TOC values coincides with the occurrence of clastic facies, and an increase in the sedimentation rate (see below), which might be responsible of an apparent dilution of the organic content in sediments under similar biological productivity, as observed in other sites (e.g., Dean 1999).

Thus, isotopically enriched $\delta^{13} \mathrm{C}_{\text {org }}$ values in Lake Estanya record correspond to periods of increased alkalinity, shallower conditions, and reduced organic productivity, whereas relatively depleted $\delta^{13} \mathrm{C}_{\text {org }}$ values, in the range of lacustrine algae, reflect reduced alkalinity, deeper conditions and increased organic matter productivity, coherent with sedimentary facies evolution and elemental geochemistry. The inverse evolution of $\delta^{13} \mathrm{C}_{\text {org }}$ and PCA axis 2 (salinity) along the sediment sequence, reinforces 
this interpretation, indicating a clear relationship between water salinity and organic productivity (Figs. 3 and 4).

\section{Biogenic silica}

Biogenic silica (Bio Si) concentration in Lake Estanya sequence is relatively low, ranging from $0 \%$ to $5 \%$ in weight, and peaking up to $13 \%$ in some intervals (Fig. 3). Opaline material is scarce throughout the lower part of the record (units VII to IV), with variable but relatively higher values in the lowermost units VII and VI, and decreasing upwards, along units V and IV. An abrupt increase is recorded at unit III, where several peaks up to $13 \%$ and $7 \%$ occur at the lower part. Unit II is characterized by variable but higher values, leading to another decrease associated to the deposition of clastic-rich unit I, characterized by relatively low values. Finally, Bio Si also increases in the uppermost subunit I.1.

Variations in biogenic silica (Bio $\mathrm{Si}$ ) mainly reflect changes in diatom primary productivity in the euphotic zone (Colman et al., 1995; Johnson, 2001). The main trends observed in the Lake Estanya Bio Si record broadly parallel changes in TOC, TN, $\delta^{13} \mathrm{C}_{\text {org }}$ and VA, thus supporting this interpretation. Generally lower values recorded throughout the lowermost part of the record (units VII to IV) coincide with generally lower TOC and TN concentrations and higher $\delta^{13} \mathrm{C}_{\mathrm{org}}$, indicative of low organic productivity. However, lower amplitude Bio Si fluctuations, such as variations within units VII, VI and III show a more complex relationship with these proxies and with abrupt, rather than gradual changes. Since larger diatoms contribute more to Bio Si than smaller ones, absolute values of VA and $\mathrm{Bio} \mathrm{Si}$ are comparable only within communities of similar taxonomic composition.

\subsection{Chronological model}


The chronology for the Lake Estanya sequence is based on 21 AMS radiocarbon dates from cores $1 \mathrm{~A}$ and $5 \mathrm{~A}$ (Tables 2 and 3). Aquatic organic matter from karstic lakes could have a significant radiocarbon reservoir effect because of the carbonate fluxes from the aquifers and watershed and due to its relation with lake dynamics it is unlikely to remain constant through time (Oldfield et al., 1997). To assess reservoir effect in Estanya, pairs of bulk organic matter samples and organic macro-remains were dated at three different core depths corresponding to the main depositional environments found along the sequence (Morellón et al., 2009) (Table 2). Accordingly, the obtained age difference has been subtracted to radiocarbon dates derived from bulk organic matter samples from similar depositional subenvironments.

In the case of Unit I, representative of a similar depositional environment to present-day lake conditions (Fig. 3), the difference between dates obtained for bulk organic matter and terrestrial macroremains has been estimated as $-585 \pm 60{ }^{14} \mathrm{C}$ yrs. For bulk organic matter samples corresponding to units II to VI, a correction of - $820 \pm$ $100{ }^{14} \mathrm{C}$ yrs was applied. Finally, in unit VIII, bulk organic matter age is $940 \pm 170$ years younger than an organic macrorest at the same core depth, suggesting the reworked nature of the latter sample selected for dating. Thus, both dates were rejected for the construction of the age model (Fig. 6 and Table 2). The chronological model for Unit I based on radiocarbon dates is coherent with sedimentation rates $(2.9 \mathrm{~mm} / \mathrm{yr})$ obtained from ${ }^{137} \mathrm{Cs}$ and ${ }^{210} \mathrm{~Pb}$ chronologies (Morellón et al., in press), and strengthen the reliability of the reservoir effect calculations for other units.

Linear sedimentation rates (LSR) obtained for clastic-dominant intervals range from $1.6 \mathrm{~mm} / \mathrm{yr}$ (subunit III.4) to $2.1 \mathrm{~mm} / \mathrm{yr}$ (unit I), whereas those obtained for the rest of the sequence range from 0.2 to $0.4 \mathrm{~mm} / \mathrm{yr}$ (Fig. 6A). Consequently, the LSR obtained with the two radiocarbon dates located within subunit III.4 was applied throughout this 
interval and subunit III.2. Thus, the four tie points obtained for the base and top of both clastic dominant intervals were introduced in the age model in order to not overestimate the time period represented by these core intervals (Fig. 6B).

The age/depth relationship for the sequence (Fig. 6A) was constructed with the 17 calibrated corrected dates (Table 3, Fig. 6A) and the four tie points (Fig. 6B). The average confidence interval of the error of the age model is ca. $150 \mathrm{yr}$. The resultant age-depth model for the Lake Estanya record described in this paper indicates that the $9.8 \mathrm{~m}$ of sediment sequence spans from ca. $21000 \mathrm{cal}$ yrs BP to the present.

\section{DISCUSSION}

Integration of sedimentary facies, elemental geochemistry, $\delta^{13} \mathrm{C}_{\mathrm{org}}$, Bio $\mathrm{Si}$ and VA data provides coherent evidence for changes in lake hydrology and limnological evolution, which can be grouped in four main stages for the last 21 cal kyrs BP: Stage 1) Last Glacial Maximum (21-18 cal kyrs BP), corresponding to the lowermost sedimentary unit VII; Stage 2) Late glacial and Early Holocene (18 - 9.4 cal kyrs BP) represented by units VI to IV; Stage 3) Mid and late Holocene period (9.4 - 1.2 cal kyrs $B P)$, equivalent to unit III; and finally, Stage 4) Last 1200 years, comprising units II and I (Fig. 7).

\subsection{Stage 1: Last Glacial Maximum (LGM) (21 - 18 cal kyrs BP)}

The oldest sediments recovered (unit VII) represent a relatively shallow carbonate-producing lake system during the LGM. Seismic stratigraphy showed that during this stage, deposition was restricted to the central areas of both sub-basins, that remained predominantly disconnected until the onset of the Holocene indicating relatively moderate to shallow lake levels (Morellón et al., 2009). Fluctuations in water level and chemical concentration led to the deposition of alternating carbonates (facies 7, predominant) and gypsum (facies 9) sequences. Additionally, higher atomic TOC/TN 
ratios suggest more terrestrial influence in the organic matter origin, compared to the upper part of the sequence (Fig. 3). The $\delta^{13} \mathrm{C}$ enrichment in organic matter $\left(\delta^{13} \mathrm{C}_{\text {org }}\right.$ ranging from -20 to $-25 \%$ ) indicates alkaline conditions and low algal productivity. Relatively high Bio Si concentration and VA is coherent with brackish waters and low organic productivity shown by sedimentological and geochemical results.

Relatively high lake levels and periods of fresh water conditions during the LGM may seem counterintuitive. These limnological features in Estanya could be interpreted as an evidence of an early stage of karstic lake development, when the hydrological system was still open because the bottom of the lake was not completely sealed off (Kindinger et al., 1999; Morellón et al., 2009). A short residence time for lake water due to a better connection with the aquifer during periods of increased subsidence could explain the absence of evaporite facies at the base of the sequence.

However, there is other regional evidence to suggest periods of relatively high water availability in Mediterranean region during the LGM. The preservation of lacustrine sediments in several records from playa-lakes in the nearby Central Ebro Basin during this period (Valero-Garcés et al., 2000a; Valero-Garcés et al., 2000b; Valero-Garcés et al., 2004; González-Sampériz et al., 2008), suggests phases of increased moisture. Furthermore, the onset of a karstification period in this region also indicates a relatively positive water balance (Valero-Garcés et al., 2004), probably related to decreased evaporation during the cold LGM.

Relatively high potassium content in the Minorca drift sequence (Frigola et al., 2008), indicating significant river flow activity and sediment delivery from the Ebro and Rhône river watersheds also points towards a relatively positive water balance in the region (Fig. 7). Although fluvial discharge from melting glaciers in Pyrenean rivers could have been smaller than during the maximum glacier extent (around 60 kyrs in the 
Cinca and Gállego rivers), there is some evidence in the form of flood deposits in LGM terraces, (Sancho et al., 2003) indicative of a period of high discharge during the LGM.

In agreement with this evidence, global vegetation reconstructions show a multifaceted pattern for non-glaciated areas of Southern Europe, with patches of deciduous forests in dominant steppe landscapes (Prentice and Jolly, 2000; Allen et al., 1999; Tzedakis, 1993). Regional vegetation reconstructions for NE Spain have also shown that cold steppe formations dominated the glacial landscapes with minor presence of conifers and restricted occurrence of mesothermophytes (Montserrat-Martí, 1992; Pérez-Obiol and Julià, 1994; González-Sampériz et al., 2005; González-Sampériz et al., 2006).

Large discrepancies between models and regional reconstructions of humidity estimations for the LGM in SW Europe and the Mediterranean Basin occur, especially in southern areas close to mountains, which are difficult to model (Kageyama et al., 2001; Ramstein et al., 2007). However, recently published high-resolution simulations show positive annual precipitation anomalies for this area (Jost et al., 2005), as a result of warmer SST than the overlying air.

In summary, the Lake Estanya record agrees with the main inferred regional trends of water availability during glacial times, in the context of global cold temperatures and reduced precipitation and evaporation reconstructed for this period. This scenario is not in conflict with periods of more positive hydrological balance because reduced summer insolation (Fig. 7) could have contributed to decrease evapotranspiration in the watershed during the summer months, contributing to relatively high lake levels without a significantly increase in rainfall.

\subsection{Stage 2: Late glacial to early Holocene (18.0 - 9.4 cal kyrs BP)}

\subsection{1 'Termination I (18.0-14.5 cal kyrs BP)'}


Generalized carbonate production in Lake Estanya finished at ca. 18.0 cal kyrs BP, leading to the establishment of a closed, permanent saline lake characterized by an evaporitic (i.e., gypsum-rich) dominant sedimentation. A significant reduction in runoff, as indicated by decreased clastic input, is synchronous with this change. $\delta^{13} \mathrm{C}_{\text {org }}$ values remain in the range -20 to $-25 \%$, indicating alkaline conditions and relatively low productivity, also recorded by decreasing Bio Si values. This aridification trend, lasting from 18.0 to 14.5 cal kyrs BP could be related to the so-called Mystery Interval (17.5 14.5 cal kyrs BP) (Denton et al., 2005; Cheng et al., 2006; Denton et al., 2006), a cooling phase in the northern Hemisphere caused by the collapse of the North Atlantic Deep Water (NADW) formation. This period has also been recorded by marine sequences around the Iberian Peninsula (IP) as a cold and dry interval (e.g., Cacho et al., 2001).

In the Lake Estanya record, the Mystery Interval (17.5 - 14.5 cal kyrs BP) was punctuated by a significant hydrological change lasting from 17.3 to 16.2 cal kyrs BP. The occurrence of finely laminated gypsum-rich facies 8 (lower unit VI) indicative of higher salinity contrasts with the dominance of planktonic diatoms indicative of fresher and pelagic conditions. This contradiction might be the result of the development of saline stratification, as observed in other saline lakes (e.g., North American Great Plains (Valero-Garcés and Kelts, 1995; Last and Vance, 1997)), with planktonic communities in the epilimnion at the same time as evaporitic minerals precipitate in the hypolimnion.

This short period $(17.3$ - 16.2 cal kyrs BP) with a more positive water balance ended abruptly in Lake Estanya, approximately coinciding with the onset of Heinrich event 1 (HE1). Distal finely laminated facies 8 were gradually substituted by cycles of clastic facies 2.2 (flooding) and banded gypsum facies 9 (dessication) typical of ephemeral lake deposition. Coherently, the low Bio Si values indicate a significant 
decrease in diatom productivity and/or preservation potential. This low lake level phase coincides with a regional maximum aridity phase recorded by the latest Artemisia expansion in the Pyrenees prior to the Holocene climatic amelioration (Jalut et al, 1992; Montserrat, 1992; Reille \& Lowe, 1993; González-Sampériz et al., 2006).

The final massive discharge of icebergs in the North Atlantic during HE1 had an important impact on the western Mediterranean Sea leading to very cold SST (Cacho et al., 1999; Sierro et al., 2005) as well as a rise in steppe taxa in the Alboran Sea (Sánchez Goñi et al., 1999; Combourieu Nebout et al., 2002; Sánchez-Goñi et al., 2002), the Iberian Margin (Naughton et al., 2007) and the Gulf of Lions (Beaudouin et al., 2005; Beaudouin et al., 2007). A climatic model for Alboran Sea predicts enhanced aridity in the continental areas, and significantly drier conditions than those recorded for the LGM (Kageyama et al., 2005), as documented by a high-resolution pollen sequence (Fletcher and Sánchez Goñi, 2008). The Estanya record provides further support to the hypothesis of periods during the late glacial which were more arid than the LGM.

\subsubsection{The Bölling/Allerod interstadial (GI2) (14.5 - 12.8 cal kyrs BP)}

Estanya lake level status remained stable, with relatively shallow, saline conditions through unit VI prevailing until 13.5 cal kyrs $\mathrm{BP}$, as indicated by the dominance of gypsum-rich facies 9 and rather stable values of the salinity and clastic input indicators as well as $\delta^{13} \mathrm{C}_{\text {org. }}$. A significant negative excursion of $\delta^{13} \mathrm{C}_{\text {org }}$ values reflects an increase in organic productivity likely related to a decrease in alkalinity, leading to lacustrine algae values and thus, deeper lake level conditions. This scenario evidences a trend towards moister and warmer conditions starting at 15 cal kyrs BP. Lake deposition returned to carbonate-rich facies 7 between 13.5 and 13.3 cal kyrs BP indicative of a brief interval of brackish water conditions and thus, a relatively more positive water balance in Lake Estanya. 
This warming trend probably corresponds to the Bölling/Allerød (B/A) interstadial (GI2), between 14.5 and 12.6 cal kyrs BP, as a result of a recovery of the NADW after the previous collapse associated to the HE1 and subsequent temperature increase of the North Atlantic Ocean (Martinson et al., 1987). This event led to a rapid rise in SST in the Iberian Atlantic Margin (Martrat et al., 2007) and the western Mediterranean basin (Cacho et al., 2001). Marine pollen sequences offshore from NW Iberia registered the first decline in herbaceous steppe association typical of glacial conditions and a more or less important expansion of deciduous trees (Naughton et al., 2007), indicative of more humid conditions. This period has been widely recorded in most continental sequences of the IP as an expansion of deciduous forests, which took place at a faster rate at mid to low altitudes of northeastern (e.g., Lake Banyoles (PérezObiol and Julià, 1994)), eastern (e.g., Navarrés (Carrión and Dupré, 1996)) and southern areas (e.g., Padul (Pons and Reille, 1988)) than in high mountain sites (Jalut et al., 1992; Montserrat-Martí, 1992; Peñalba et al., 1997; González-Sampériz et al., 2006) and northwestern Spain (Ramil-Rego, 1993; Allen et al., 1996; van der Knaap and van Leeuwen, 1997).

\subsubsection{The Younger Dryas (GS1) (12.8 - 11.6 cal kyrs BP)}

The B/A interstadial period was followed by a lake-level drop and salinity increase in Estanya, as indicated by the return towards the deposition of gypsum-rich facies 9 at the mid and upper part of unit $\mathrm{V}$, and an abrupt decrease in organic productivity (marked by positive excursion of $\delta^{13} \mathrm{C}_{\text {org }}$ and a sharp decrease in Bio Si, compared to previous $\mathrm{B} / \mathrm{A}$ values). The extremely low values of $\mathrm{Bio} \mathrm{Si}$ recorded between 12.8 and 11.8 cal kyrs BP correlate with the near absence of diatoms, which occurs for the first time throughout the record, indicating either almost total desiccation 
or extremely alkaline conditions responsible for frustule dissolution, as observed in other shallow saline lakes of the Iberian Peninsula (Reed, 1998).

According to the age model, this cold and arid phase coincides with the Younger Dryas (YD) Stadial (GS1) (12.9 - 11.7 cal kyrs BP), characterized by a generalized return towards colder and arid conditions in Europe and the Mediterranean Basin (Björck et al., 1998). The palaeoceanographic impact of this event has been widely detected in the Mediterranean Sea (Cacho et al., 2001) as a brief return towards glacial conditions, marked by a SST drop and the reappearance of polar foraminifera Neogloboquadrina Pachyderma (Cacho et al., 1999; Martrat et al., 2007; Frigola et al., 2008). Marine pollen sequences derived from these sites also point towards colder and arid conditions (Sánchez Goñi et al., 1999). Varved lacustrine sequences over Central and North Europe have also shown an immediate, quasi synchronous response to changes derived from Greenland ice core records characterized by colder and drier conditions likely caused by intensified westerly winds (Litt et al., 2001; Brauer et al., 2008).

However, different responses are observed in continental Iberia. In contrast to the earlier $\mathrm{B} / \mathrm{A}$ interstadial, environmental changes during the $\mathrm{YD}$ appear to be more marked in mountainous areas (e.g., the Pyrenees (González-Sampériz et al., 2006), or the Iberian Range (Vegas et al., 2003)) than in mid-to-low altitude sites (e.g. Lake Banyoles, (Pérez-Obiol and Julià, 1994)) and southern Iberia (e.g., Padul (Pons and Reille, 1988); Lake Siles, (Carrión, 2002); Navarrés (Carrión and Van Geel, 1999)), reflecting a complex pattern of environmental responses. In Lake Estanya, synchronous response of water chemistry and productivity proxies indicates an abrupt hydrological change driven by more arid conditions.

\subsubsection{Early Holocene (11.6 - 9.4 cal kyrs BP)}


Lake Estanya experienced a new lake-level drop after the YD and prior to the onset of the Holocene. During this period (11.6 - 9.4 cal kyrs BP), represented by unit IV, Lake Estanya was a shallow, ephemeral, saline lake - mud flat complex with carbonate-dominated sedimentation during flooding episodes (facies 6), and gypsum precipitation (facies 10) during desiccation phases. The occurrence of interstitial and intra-sedimentary gypsum crystals and presence of dolomite are suggestive of predominantly shallow conditions (Schreiber and Tabakh, 2000) (Fig. 3). During this interval, the geochemical and mineralogical proxies indicate an increase in clay content that commonly occurs in ephemeral lake systems with higher alluvial and aeolian input (Cohen, 2003) (Fig. 5). Low Bio Si and low VA are coherent with dominant ephemeral lake conditions. Sedimentological and geochemical proxies indicate that the lowest lake level of the sequence was reached during this period.

However, other NE Spain sequences as El Portalet (González-Sampériz et al., 2006) or Banyoles (Pérez-Obiol and Julià, 1994) (Fig. 7) document an immediate response of regional vegetation to the $\mathrm{YD} /$ Holocene transition. This mismatch between local hydrological conditions and regional vegetation signal can be attributed to the specific features of the sedimentary basin (groundwater-fed) as described in other lakes (Lake Salines (Giralt et al., 1999)). On the other hand, increased summer temperatures might have favoured lower lake levels (Fig. 7) due to enhanced evapotranspiration, but might secondarily favour the development of M-T vegetation.

The progressive dominance of facies 6 over facies 10 after 9.9 cal kyrs BP indicates a slight increase in humidity, in agreement with the negative excursion of $\delta^{13} \mathrm{C}_{\text {org }}$ reflecting enhanced algal productivity and decreased alkalinity. The slight increase in Bio Si, also suggests less alkalinity and/or permanent shallow conditions. Finally, full Holocene conditions are reached after an abrupt transition at 9.4 cal kyrs 
BP, when facies 6 are drastically substituted by deeper facies 5 and Bio Si content increases dramatically. The onset of unit III, represents a large hydrological and limnological change in the lake, starting with a plant debris-rich layer deposited throughout the lake basin, indicative of an extreme runoff event, possibly responsible for the rise of lake level. An increase in magnitude and frequency of precipitation and surface runoff would explain the lake level rise and the establishment of a relatively deep saline lake. Seismic stratigraphy also shows this transgressive event and that both subbasins were predominantly connected during the Holocene (Morellón et al., 2009).

This delayed hydrological response to the onset of the Holocene has also been documented in several sites of the Mediterranean Basin. In fact, Lake Banyoles, a representative sequence from NE Spain (Pérez-Obiol and Julià, 1994), has also recorded the final decrease in steppe taxa at 9.5 cal kyrs BP; and in Lake Salines (Giralt et al., 1999), stable hydrological conditions in the basin were not reached before 10 kyrs. Accordingly, Early Holocene pollen records from the Alboran Sea, dominated by evergreen Quercus, Artemisia and Cupressaceae, experienced a rapid increase in deciduous oaks after 9.4 cal kyrs BP (Fletcher and Sánchez Goñi, 2008). The coincidence of this situation with the onset of humid conditions in North Morocco at $8500{ }^{14} \mathrm{C}$ yrs (about 9500 cal yrs BP) shown by the rise in Quercus (Lamb et al., 1989) is remarkable, and is also recorded by marine pollen sequences (Marret and Turon, 1994).

Alternatively the delay in the hydrological response of Lake Estanya could be due to the different response time of depositional systems and vegetation to similar hydrological and climate forcings. As explained above, most changes in sedimentary facies respond to threshold values, generating apparent abrupt changes not recorded by other proxies. In Lake Salines, mesic pollen taxa increased at the beginning of the 
Holocene (10 $000{ }^{14} \mathrm{C}$ yrs BP, ca. $11500 \mathrm{cal}$ yrs BP), the first lacustrine biota appeared at $9500{ }^{14} \mathrm{C}$ yrs $\mathrm{BP}$ (ca. 10800 cal yrs $\mathrm{BP}$ ), and the main change in lacustrine depositional environment occurred later at $9000{ }^{14} \mathrm{C}$ yrs BP (ca. 10000 cal yrs BP) (Giralt et al., 1999). This time lag has been interpreted as a result of different systems responses to a gradual increase in water availability.

\subsection{Stage 3: Mid to late Holocene}

\subsubsection{Mid Holocene (9.4 - 4.8 cal kyrs BP)}

The increase in water level led to the establishment of a saline, permanent, relatively deep lake with development of organic - rich facies with microbial mats (facies 5) and gypsum (facies 4) lasting until 4.8 cal kyrs BP (low to mid sedimentary unit III). This change is also reflected by more negative $\delta^{13} \mathrm{C}_{\text {org }}$ trend, that remain stable throughout this period reaching values of about $-30 \%$, indicative of lower alkalinity and enhanced algal productivity (Meyers and Lallier-Vergès, 1999). Both, the presence of microbial mats and the high abundance of benthic diatoms suggest higher but moderate lake levels. This relatively humid phase recorded in Lake Estanya coincides with the Holocene Climatic Optimum, a period characterized by the warmest and moistest conditions of the Holocene, with the most important expansion of deciduous forests elsewhere in the Mediterranean region and Central Europe (Magny, 2002).

Abrupt environmental changes occurring within this period are indicated in Estanya sequence by changes in salinity and organic productivity (Fig. 7). Periods of increased runoff and sediment delivery from the catchment are recorded by the deposition of clastic facies in subunits III.2, III.4 and III.6 (Fig. 3) resulting in peaks in clastic input and by low salinity values (Fig. 7). The deposition of these layers, centred around 8.6, 6.2 and 4.8 cal kyrs BP according to our chronological model, can be attributed to short-lived episodes likely caused by intense runoff events in the 
watershed. However, the occurrence of several mm-thick fining upwards sequences within these layers indicates that they do not represent single detrital input events, but brief periods of clastic-dominant sedimentation probably reflecting increased runoff and sediment delivery in the watershed.

Although some records from the IP (Laguna Medina; Reed et al., 2001), the nearby Pyrenees (González-Sampériz et al., 2006) and the southern Ebro valley (González-Sampériz et al., 2009) have shown an impact of the the so-called 8.2 ka event (Alley and Ágústsdóttir, 2005) in hydrology, vegetation and even in patterns of human occupation no clear evidence has been found in Estanya. The observed increase in sulphur, related to enhanced gypsum precipitation (Figs. 4 and 5), the higher salinity and relatively low biological productivity deduced from Bio Si and $\delta^{13} \mathrm{C}_{\mathrm{org}}$ (Fig. 7) are all indicative of relatively arid conditions around this event. However, the chronological resolution is too low and the intensity of this excursion as deduced by the comparison with previous late glacial fluctuations suggests a small response to the $8.2 \mathrm{ka}$ cooling event.

Regional pollen records show a vegetation dominated by the deciduous tree component and parallel to the almost dissapeareance of the steppe taxa, reflecting the warmer and moister conditions that characterize the Climatic Optimum here (Montserrat-Martí, 1992; Stevenson, 2000; González-Sampériz et al., 2006); and elsewhere in the IP (e.g., Pons and Reille, (1988); Reed et al., (2001); Carrión, (2002); Dorado-Valiño et al., (2002), among others) and southern Europe (Prentice and Webb, 1998; Rossignol-Strick, 1999; Jalut et al., in press). Palaeoclimatic models (Cheddadi et al., 1996; Brewer et al., 2007; Wu et al., 2007) also predict warmer and moister conditions for this period.

\subsubsection{Late Holocene (4.8 to 1.2 cal kyrs BP)}


More saline and shallower conditions were dominant again in Lake Estanya between 4.8 and 1.2 cal kyrs BP, as indicated by the deposition of gypsum-rich facies 10 and massive sapropels facies 4 (subunit III.1), the frequent development of coarser grain size gypsum nodules (Fig. 3) and the reduced detrital input from the catchment, restricted to $\mathrm{cm}$-thick clastic intercalations (Fig. 3). This aridification trend coincides with the end of the African Humid Period (de Menocal et al., 2000; Gasse, 2000). However, in Lake Estanya the transition is progressive rather than abrupt, in agreement with the gradual response of terrestrial ecosystems to mid Holocene change in N Africa lakes (Kropelin et al., 2008).

The most arid conditions within this period occurred between 4.8 and 4 cal kyrs $\mathrm{BP}$, as marked by relative maximum salinity values, more positive $\delta^{13} \mathrm{C}_{\text {org }}$ values indicative of maximum alkalinity and decreased algal productivity. This relatively dry phase has been widely detected in the IP (Pons and Reille, 1988; Davis, 1994; van der Knaap and van Leeuwen, 1995; Yll et al., 1997; Reed et al., 2001; Carrión et al., 2003; Carrión et al., 2007; González-Sampériz et al., 2008) and elsewhere in the Mediterranean basin (Roberts et al., 2001; Sadori and Narcisi, 2001; Magny, 2002; BarMatthews, 2003).

\subsubsection{Stage 4: The last 1200 years}

A transition towards less saline conditions, higher lake level and increased runoff started at about 1200 cal yr BP with deposition of subunit II.2 (1200 cal yrs BP to 870 cal yrs BP) (Fig. 7). This transgressive period was interrupted by the deposition of a thick gypsum layer (subunit II.1, 870 to 750 cal yrs. BP) indicative of a sharp drop in lake level and increased salinity, accompanied by higher $\delta^{13} \mathrm{C}_{\mathrm{org}}$, and decreased Bio Si. The timing of this period coincides with the the Medieval Climate Anomaly, a period of warmer temperatures and widespread aridity in southern Europe (Bradley et 
al., 2003). In Lake Estanya it also correlates with the conquest of the territory by the Christians (Riera et al., 2004) and the beginning of large changes in the landscape and the watershed with farming activities and irrigation.

A major depositional change occurred at 750 cal yrs BP marked by the substitution of organic and gypsum-rich by clastic-rich facies, similar to the present-day deposits. This thick clastic sequence (sedimentary unit I) was continuously deposited throughout the whole lake basin as indicated by seismic data, marking a transgressive episode (Morellón et al., 2009). A deep brackish to freshwater lake with seasonal water stratification, more negative $\delta^{13} \mathrm{C}_{\mathrm{org}}$ values and higher Bio $\mathrm{Si}$ and VA, indicative of lower alkalinity and enhanced algal productivity is established. This environmental change could be due to an increase in humidity, as observed in other Spanish lakes (e.g., Taravilla (Moreno et al., 2008), Zoñar (Martín-Puertas et al., 2008)) and fluvial deposits (Benito et al., 2003).

The remarkable rise in the linear sedimentation rate (from 0.30 to $2.11 \mathrm{~mm} / \mathrm{yr}$ ) (Fig. 6) is likely the result of land-use changes and/or forest clearances, derived from the Christian conquest of the area in the $12^{\text {th }}$ century (Riera et al., 2004). Additionally, evidences of an old canal of the same age connecting the main lake with the small 'Estanque Grande de Arriba' also exist (Riera et al., 2004). However, given the low volume of this lake in comparison with the main lake, 'Estanque Grande de Abajo', this rise in water level cannot be exclusively attributed to this connection. Lake catchment deforestation may have contributed to reduce water interception, increasing soil permeability and favouring aquifer recharge, thus contributing to a rise in lake level (López-Moreno et al., 2008). Further research will clarify the role of human management and climate change in this major last phase of environmental transformation occurred in Lake Estanya during the last centuries. 


\section{CONCLUSIONS}

Lake Estanya has experienced significant hydrological fluctuations over the last $21 \mathrm{kyrs}$, in response to climate variability. In agreement with most reconstructions, generally arid and cold conditions, reflected by moderate to shallow lake levels, high salinity and reduced organic productivity prevailed during lateglacial times, whereas higher lake levels prevailed during the Holocene period.

Although most regional records indicate that the LGM was a generally cold and arid period, in Lake Estanya moderate lake levels occurred and it was not the most arid interval recorded in the last 21 cal kyrs BP. The LGM was followed by a marked increase in aridity, coinciding with the Mystery Interval (18 - 14.5 cal kyrs BP), also detected in other regional sequences. Moister conditions characterized the period 14.5 to 12.6 cal kyrs BP, corresponding to the B/A interstadial, and an abrupt lake level drop, which led to the establishment ephemeral conditions, occurred during the YD (12.9 11.6 cal kyrs BP).

A significant delay in the hydrological response to external events occurred at the onset of the Holocene. Shallow to ephemeral conditions prevailed in Estanya until 9.4 cal kyrs BP, when an abrupt lake level rise took place, leading to the establishment of a deeper saline lake characterized by extensive development of microbial mats and better diatom preservation throughout the Holocene. Similar patterns of inferred climate change have been described in other southern Iberian and N African sequences.

Subsequently, two arid phases occur during the late Holocene. A significant decline in lake level took place during the mid Holocene $(4.8-4.0$ cal kyrs BP) reflecting a gradual rather than abrupt hydrological change, in agreement with lake records from northern Africa. A smaller lake-level decrease occurred during the Medieval Climate Anomaly. A major increase in lake level, accompanied by higher 
runoff and sediment delivery, took place at 1.2 cal kyrs BP, leading to the establishment of modern lake conditions.

\section{ACKNOWLEDGEMENTS}

This research has been funded through the projects LIMNOCLIBER (REN200309130-C02-02), IBERLIMNO (CGL2005-20236-E/CLI), LIMNOCAL (CGL200613327-C04-01), PALEODIVERSITAS (CGL2006-02956/BOS), GRACCIE (CSD2007-00067); provided by the Spanish Inter-Ministry Commission of Science and Technology (CICYT); and PIRINEOSABRUPT (PM073/2007), provided by the Diputación General de Aragón. Additional funding for XRD analyses (Univ. of Cádiz) and geochemical analyses (EEZ-CSIC and MARUM Centre) was provided by the Aragonese Regional Government - CAJA INMACULADA by means of 2 travel grants.

M. Morellón and J.P. Corella are supported by PhD contracts with the CONAI+D (Aragonese Scientific Council for Research and Development) and A. Moreno and M. Rico hold post-doctoral contracts funded by the ESF ('Marie Curie programme') and the Spanish Ministry of Science and Innovation ('Juan de la Cierva programme'), respectively. We are indebted to Anders Noren, Doug Schnurrenberger and Mark Shapley (LRC-Univ. of Minnesota) for the 2004 coring campaign and Santiago Giralt and Armand Hernández (IJA-CSIC), as well as Alberto Sáez and J.J. Pueyo-Mur (Univ. of Barcelona) for coring assistance in 2006. We thank Andrés Ospino for his help in diatom sample treatment and slide mounting and Marco Klann (MARUM Centre, Univ. of Bremen) for biogenic silica analyses. We are also grateful to EEZ-CSIC, EEAD-CSIC and IPE-CSIC laboratory staff for their collaboration in this research. We thank Santiago Giralt and anonymous reviewer for their helpful comments and their criticism, which led to a considerable improvement in the manuscript.

\section{REFERENCES}


Abrantes, F., Gil, I., Lopes, C., Castro, M., 2005. Quantitative diatom analyses: a faster cleaning procedure. Deep Sea Research Part I: Oceanographic Research Papers, 52(1), 189-198.

Allen, J.R.M., Brandt, U., Brauer, A., Hubbertens, H., Huntley, B., Keller, J., Kraml, M., Mackensen, A., Mingram, J., Negendank, J.F.W., Nowaczyk, N.R., Oberhänsli, H., Watts, W.A., Wulf, S., Zolitschka, B., 1999. Rapid environmental changes in southern Europe during the last glacial period. Nature, 400(Letters to Nature), 740-743.

Allen, J.R.M., Huntley, B., Watts, W.A., 1996. The vegetation and climate of northwest Iberia over the last 14,000 years. Journal of Quaternary Science, 11(2), 125-147.

Alley, R.B., Ágústsdóttir, A.M., 2005. The 8k event: cause and consequences of a major Holocene abrupt climate change. Quaternary Science Reviews, 24, 1123-1149.

Ávila, A., Burrel, J.L., Domingo, A., Fernández, E., Godall, J., Llopart, J.M., 1984. Limnología del Lago Grande de Estanya (Huesca). Oecologia aquatica, 7, 3-24.

Bar-Matthews, M., Ayalon, A., Gilmour, M., Matthews, A., Hawkesworth, C.J., 2003. Sea-land oxygen isotopic relationship from planktonic foraminifera and speleothems in the Eastern Mediterranean region and their implication for paleorainfall during interglacial interval. Geochimica et Cosmochimica Acta, 67(17), 3181-3199.

Beaudouin, C., Jouet, G., Suc, J.-P., Berne, S., Escarguel, G., 2007. Vegetation dynamics in southern France during the last $30 \mathrm{ky}$ BP in the light of marine palynology. Quaternary Science Reviews, 26(7-8), 1037-1054.

Beaudouin, C., Suc, J.-P., Acherki, N., Courtois, L., Rabineau, M., Aloïsi, J.-C., Sierro, F.J., Oberlin, C., 2005. Palynology of the northwestern Mediterranean shelf 
(Gulf of Lions): First vegetational record for the last climatic cycle. Marine and Petroleum Geology, 22(6-7), 845-863.

Benito, G., Sopeña, A., Sánchez-Moya, Y., Machado, M.J., Pérez-González, A., 2003. Palaeoflood record of the Tagus River (Central Spain) during the Late Pleistocene and Holocene. Quaternary Science Reviews, 22(15-17), 1737-1756.

Björck, S., Walker, M.J.C., Cwynar, L.C., Johnsen, S., Knudsen, K.-L., Lowe, J.J., Wohlfarth, B., INTIMATE Members, 1998. An event stratigraphy for the Last Termination in the North Atlantic region based on the Greenland ice-core record: a proposal by the INTIMATE group. Journal of Quaternary Science, 13(4), 283-292.

Blanco-Castro, E., Casado, M., Costa, M., Escribano, R., García Antón, M., Génova, M., Gómez, A., Moreno, J., Morla, C., Regato, P., Sainz Ollero, H., 1997. Los bosques ibéricos. Una interpretación geobotánica. Planeta, Barcelona (Spain), $572 \mathrm{pp}$.

Boessenkool, K.P., Brinkhuis, H., Schönfeld, J., Targarona, J., 2001. North Atlantic seasurface temperature changes and the climate of western Iberia during the last deglaciation; a marine palynological approach. Global and Planetary Change, 30(1-2), 33-39.

Bradley, R.S., Hughes, M.K., Diaz, H.F., 2003. Climate Change: Climate in Medieval Time. Science, 302(5644), 404-405.

Brauer, A., Haug, G.H., Dulski, P., Sigman, D.M., Negendank, J.F.W., 2008. An abrupt wind shift in western Europe at the onset of the Younger Dryas cold period. Nature Geosciences, 1(8), 520-523. 
Brenner, M., Whitmore, T.J., Curtis, J.H., Hodell, D.A., Schelske, C.L., 1999. Stable isotope $\left(\delta^{13} \mathrm{C}\right.$ and $\left.\delta^{15} \mathrm{~N}\right)$ signatures of sedimented organic matter as indicators of historic lake trophic state. Journal of Paleolimnology, 22(2), 205-221.

Brewer, S., Guiot, J., Torre, F., 2007. Mid-Holocene climate change in Europe: a datamodel comparison. Climate of the Past, 3(3), 499-512.

Cacho, I., Grimalt, J.O., Canals, M., Sbaffi, L., Shackleton, N.J., Schonfeld, J., Zahn, R., 2001. Variability of the western Mediterranean Sea surface temperature during the last 25,000 years and its connection with the Northern Hemisphere climatic changes. Paleoceanography, 16(1), 40-52.

Cacho, I., Grimalt, J.O., Pelejero, C., Canals, M., Sierro, F.J., Flores, J.A., Shackleton, N., 1999. Dansgaard-Oeschger and Heinrich event imprints in Alboran Sea paleotemperatures. Paleoceanography, 14, 698-705.

Cambra, J., 1991. Contribució a l'estudi de les algues epifítiques dels estanys de Banyoles, Basturs i Estanya. Orsis, 6, 27-44.

Carrión, J.S., 2002. Patterns and processes of Late Quaternary environmental change in montane region of southwestern Europe. Quaternary Science Reviews, 21, 20472066.

Carrión, J.S., Dupré, M., 1996. Late Quaternary Vegetational History at Navarrés, Eastern Spain. A Two Core Approach. New Phytologist, 134(1), 177-191.

Carrión, J.S., Fuentes, N., González-Sampériz, P., Sánchez Quirante, L., Finlayson, J.C., Fernández, S., Andrade, A., 2007. Holocene environmental change in a montane region of southern Europe with a long history of human settlement. Quaternary Science Reviews, 26(11-12), 1455-1475. 
Carrión, J.S., Sánchez-Gómez, P., Mota, J.F., Yll, R., Chain, C., 2003. Holocene vegetation dynamics, fire and grazing in the Sierra de Gador, southern Spain. The Holocene, 13(6), 839-849.

Carrión, J.S., Van Geel, B., 1999. Fine-resolution Upper Weichselian and Holocene palynological record from Navarres (Valencia, Spain) and a discussion about factors of Mediterranean forest succession. Review of Palaeobotany and Palynology, 106(3-4), 209-236.

Cohen, A.S., 2003. Paleolimnology: The history and evolution of lake systems. Oxford University Press, New York, 500 pp.

Colman, S.M., Peck, J.A., Karabanov, E.B., Carter, S.J., Bradbury, J.P., King, J.W., Williams, D.F., 1995. Continental climate response to orbital forcing from biogenic silica records in Lake Baikal. Nature, 378, 769-771.

Combourieu Nebout, N., Turon, J.L., Zahn, R., Capotondi, L., Londeix, L., Pahnke, K., 2002. Enhanced aridity and atmospheric high-pressure stability over the western Mediterranean during the North Atlantic cold events of the past 50 k.y. Geology, 30(10), 863-866.

Cuadrat, J.M., Saz Sánchez, M.A., Vicente Serrano, S.M., 2008. Atlas climático de Aragón. Departamento de Medio Ambiente. Gobierno de Aragón.

Chapman, M.R., Shackleton, N.J., Duplessy, J.-C., 2000. Sea surface temperature variability during the last glacial-interglacial cycle: assessing the magnitude and pattern of climate change in the North Atlantic. Palaeogeography, Palaeoclimatology, Palaeoecology, 157(1-2), 1-25.

Cheddadi, R., Yu, G., Guiot, J., Harrison, S.P., Prentice, I.C., 1996. The climate of Europe 6000 years ago. Climate Dynamics, 13(1), 1-9. 
Cheng, H., Edwards, R.L., Wan, Y.J., Ko, X.G., Ming, Y.F., Kelly, M.J., Wang, X.F., Gallup, C.D., Liu, W.G., 2006. A penultimate glacial monsoon record from Hulu Cave and two-phase glacial terminations. Geology, 34(3), 217-220.

Chung, F.H., 1974a. Quantitative interpretation of X-ray diffraction patterns of mixtures. I. Matrix-flushing method for quantitative multicomponent analysis. Journal of Applied Crystallography, 7(519-525).

Chung, F.H., 1974b. Quantitative interpretation of X-ray diffraction patterns of mixtures. II. Adiabatic principle of X-ray diffraction analysis of mixtures. Journal of Applied Crystallography, 7, 526-531.

Davis, B.A.S., 1994. Paleolimnology and Holocene environmental change from endorheic lakes in the Ebro Basin, north-east Spain. Unpublished PhD Thesis, University of Newcastle upon Tyne, $317 \mathrm{pp}$.

Davis, B.A.S., Stevenson, A.C., 2007. The $8.2 \mathrm{ka}$ event and Early-Mid Holocene forests, fires and flooding in the Central Ebro Desert, NE Spain. Quaternary Science Reviews, 26(13-14), 1695-1712.

de Abreu, L., Shackleton, N.J., Schönfeld, J., Hall, M.A., Chapman, M.R., 2003. Millennial-scale oceanic climate variability off the Western Iberian margin during the last two glacial periods. Marine Geology, 196, 1-20.

De Master, D.J., 1981. The supply and accumulation of silica in the marine environment. Geochimica et Cosmochimica Acta, 32, 1128-1140.

Dean, W.E., 1999. The carbon cycle and biogeochemical dynamics in lake sediments. Journal of Paleolimnology, 21, 375-393.

deMenocal, P., Ortiz, J., Guilderson, T., Adkins, J., Sarnthein, M., Baker, L., Yarusinsky, M., 2000. Abrupt onset and termination of the African Humid 
Period: rapid climate responses to gradual insolation forcing. Quaternary Science Reviews, 19(1-5), 347-361.

Denton, G.H., Alley, R.B., Comer, G.C., Broecker, W.S., 2005. The role of seasonality in abrupt climate change. Quaternary Science Reviews, 24(10-11), 1159-1182.

Denton, G.H., Broecker, W.S., Alley, R.B., 2006. The mystery interval 17.5 to 14.5 kyrs ago. PAGES News, 14(2), 14-16.

Dorado-Valiño, M., Valdeolmillos-Rodríguez, A., Ruiz-Zapata, M.B., Gil-García, M.J., de Bustamante-Gutiérrez, I., 2002. Climatic changes since the Lateglacial/Holocene transition in La Mancha Plain (South-central Iberian Peninsula, Spain) and their incidence on Las Tablas de Daimiel marshlands. Quaternary International, 93-94, 73-84.

Ferrio, J.P., Alonso, N., López, J.B., Araus, J.L., Voltas, J., 2006. Carbon isotope composition of fossil charcoal reveals aridity changes in the NW Mediterranean Basin. Global Change Biology, 12(7), 1253-1266.

Fletcher, W.J., Sánchez Goñi, M.F., 2008. Orbital- and sub-orbital-scale climate impacts on vegetation of the western Mediterranean basin over the last 48,000 yr. Quaternary Research, in press.

Frigola, J., Moreno, A., Cacho, I., Canals, M., Sierro, F.J., Flores, J.A., Grimalt, J.O., 2008. Evidence of abrupt changes in Western Mediterranean Deep Water circulation during the last 50 kyr: A high-resolution marine record from the Balearic Sea. Quaternary International, 181(1), 88-104.

Frigola, J., Moreno, A., Cacho, I., Canals, M., Sierro, F.J., Flores, J.A., Grimalt, J.O., Hodell, D.A., Curtis, J.H., 2007. Holocene climate variability in the western Mediterranean region from a deepwater sediment record. Paleoceanography, 22(2). 
García-Herrera, R., Gimeno, L., Ribera, P., Hernández, E., 2005. New records of Atlantic hurricanes from Spanish documentary sources. Journal of Geophysical Research, 110(D03109), doi:10.1029/2004JD005272. .

Gasse, F., 2000. Hydrological changes in the African tropics since the Last Glacial Maximum. Quaternary Science Reviews, 19, 189-211.

Giralt, S., Burjachs, F., Roca, J.R., Julià, R., 1999. Late Glacial to Early Holocene environmental adjustment in the Mediterranean semi-arid zone of the Salines playa-lake (Alacante, Spain). Journal of Paleolimnology, 21, 449-460.

Giralt, S., Moreno, A., Bao, R., Sáez, A., Prego, R., Valero-Garcés, B., Pueyo, J., González-Sampériz, P., Taberner, C., 2008. A statistical approach to disentangle environmental forcings in a lacustrine record: the Lago Chungará case (Chilean Altiplano). Journal of Paleolimnology, 40(1), 195-215.

González-Sampériz, P., 2004. Evolución paleoambiental del sector central de la Cuenca del Ebro durante el Pleistoceno Superior y Holoceno. Instituto Pirenaico de Ecología - C.S.I.C., Departamento de Ciencias de la Antigüedad (Universidad de Zaragoza), Zaragoza, $210 \mathrm{pp}$.

González-Sampériz, P., Valero-Garcés, B.L., Carrión, J.S., Peña-Monné, J.L., GarcíaRuiz, J.M., Martí-Bono, C., 2005. Glacial and Lateglacial vegetation in northeastern Spain: New data and a review. Quaternary International, 140-141, 4-20.

González-Sampériz, P., Valero-Garcés, B.L., Moreno, A., Jalut, G., García-Ruiz, J.M., Martí-Bono, C., Delgado-Huertas, A., Navas, A., Otto, T., Dedoubat, J.J., 2006. Climate variability in the Spanish Pyrenees during the last 30,000 yr revealed by the El Portalet sequence. Quaternary Research, 66(1), 38-52. 
González-Sampériz, P., Valero-Garcés, B.L., Moreno, A., Morellón, M., Navas, A., Machín, J., Delgado-Huertas, A., 2008. Vegetation changes and hydrological fluctuations in the Central Ebro Basin (NE Spain) since the Late Glacial period: Saline lake records. Palaeogeography, Palaeoclimatology, Palaeoecology, 259(2-3), 157-181.

Gutiérrez-Elorza, M., Peña-Monné, J.L., 1998. Geomorphology and late Holocene climatic change in Northeastern Spain. Geomorphology, 23, 205-217.

Gutiérrez, M., Gutiérrez, F., Desir, G., 2006. Considerations on the chronological and causal relationships between talus flatirons and palaeoclimatic changes in central and northeastern Spain. Geomorphology, 73, 50-63.

Harrison, S.P., Yu, G., Tarasov, P.E., 1996. Late Quaternary Lake-Level Record from Northern Eurasia. Quaternary Research, 45(2), 138-159.

Heegaard, E., Birks, H.J.B., Telford, R.J., 2005. Relationships between calibrated ages and depth in stratigraphical sequences: an estimation procedure by mixed-effect regression. The Holocene, 15(4), 612-618.

Hoek, W.Z., Yu, Z.C., Lowe, J.J., 2008. INTegration of Ice-core, MArine, and TErrestrial records (INTIMATE): refining the record of the Last GlacialInterglacial Transition. Quaternary Science Reviews, 27(1-2), 1-5.

IGME, 1982. Mapa Geológico de España 1:50000 No. 289. Benabarre. Instituto Geológico y Minero de España, Madrid.

Jalut, G., Jacques Dedoubat, J., Fontugne, M., Otto, T., in press. Holocene Circum Mediterranean vegetation changes: Climate forcing and human impact. Quaternary International, doi:10.1016/j.quaint.2008.03.012

Jalut, G., Marti, J.M., Fontugne, M., Delibrias, G., Vilaplana, J.M., Julià, R., 1992. Glacial to interglacial vegetation changes in the northern and southern Pyrenees: 
Deglaciation, vegetation cover and chronology. Quaternary Science Reviews, 11(4), 449-480.

Jansen, E., Overpeck, J., Briffa, K.R., Duplessy, J.-C., Joos, F., Masson-Delmotte, V., Olago, D., Otto-Bliesner, B., Peltier, W.R., Rahmstorf, S., Ramesh, R., Raynaud, D., Rind, D., Solomina, O., Villalba, R., Zhang, D., 2007. Palaeoclimate. In: Climate Change 2007: The Physical Science Basis., Intergovernmental Panel on Climate Change, Cambridge, United Kingdom and New York, NY, USA.

Johnson, T.C., Barry, S.L., Chan, Y., Wilkinson, 2001. Decadal record of climate variability spanning the past $700 \mathrm{yr}$ in the Southern Tropics of East Africa. Geology, 29(1), 83-86.

Jost, A., Lunt, D., Kageyama, M., Abe-Ouchi, A., Peyron, O., Valdes, P., Ramstein, G., 2005. High-resolution simulations of the last glacial maximum climate over Europe: a solution to discrepancies with continental palaeoclimatic reconstructions? Climate Dynamics, 24(6), 577-590.

Kageyama, M., Nebout, N.C., Sepulchre, P., Peyron, O., Krinner, G., Ramstein, G., Cazet, J.-P., 2005. The Last Glacial Maximum and Heinrich Event 1 in terms of climate and vegetation around the Alboran Sea: a preliminary model-data comparison. Comptes Rendus Geosciences, 337(10-11), 983-992.

Kageyama, M., Peyron, O., Pinot, S., Tarasov, P., Guiot, J., Joussaume, S., Ramstein, G., 2001. The Last Glacial Maximum climate over Europe and western Siberia: a PMIP comparison between models and data. Climate Dynamics, 17(1), 23-43.

Keeley, J.E., Sandquist, D.R., 1992. Carbon: freshwater plants. Plant, Cell \& Environment, 15(9), 1021-1035. 
Kindinger, J.L., Davis, J.B., Flocks, J.G., 1999. Geology and evolution of lakes in north-central Florida. Environmental Geology, 38(4), 301-321.

Kohfeld, K.E., Harrison, S.P., 2000. How well can we simulate past climates? Evaluating the models using global palaeoenvironmental datasets. Quaternary Science Reviews, 19(1-5), 321-346.

Kropelin, S., Verschuren, D., Lezine, A.M., Eggermont, H., Cocquyt, C., Francus, P., Cazet, J.P., Fagot, M., Rumes, B., Russell, J.M., Darius, F., Conley, D.J., Schuster, M., von Suchodoletz, H., Engstrom, D.R., 2008. Climate-Driven Ecosystem Succession in the Sahara: The Past 6000 Years. Science, 320(5877), 765-768.

Lamb, H.F., Eicher, U., Switsur, V.R., 1989. An 18,000-Year Record of Vegetation, Lake-Level and Climatic Change from Tigalmamine, Middle Atlas, Morocco. Journal of Biogeography, 16(1), 65-74.

Last, W.M., Vance, R.E., 1997. Bedding characteristics of Holocene sediments from salt lakes of the northern Great Plains, Western Canada. Journal of Paleolimnology, 17(3), 297-318.

León-Llamazares, A., 1991. Caracterización agroclimática de la provincia de Huesca Ministerio de Agricultura, Pesca y Alimentación (M.A.P.A.), Madrid.

Litt, T., Brauer, A., Goslar, T., Merkt, J., Balaga, K., Müller, H., Ralska-Jasiewiczowa, M., Stebich, M., Negendank, J.F.W., 2001. Correlation and synchronisation of Lateglacial continental sequences in northern central Europe based on annually laminated lacustrine sediments. Quaternary Science Reviews, 20(11), 12331249. 
López-Moreno, J.I., García-Ruiz, J.M., Beniston, M., 2008. Environmental Change and water management in the Pyrenees. Facts and future perspectives for Mediterranean mountains. Global and Planetary Change, 66(3-4), 300-312.

López-Vicente, M., 2007. Erosión y redistribución del suelo en agroecosistemas mediterráneos: Modelización predictiva mediante SIG y validación con ${ }^{137} \mathrm{Cs}$ (Cuenca de Estaña, Pirineo Central). PhD Thesis, Universidad de Zaragoza, Zaragoza, $212 \mathrm{pp}$.

Luzón, A., Pérez, A., Mayayo, M.J., Soria, A.R., Sánchez Goñi, M.F., Roc, A.C., 2007. Holocene environmental changes in the Gallocanta lacustrine basin, Iberian Range, NE Spain. The Holocene, 17(5), 649-663.

Mackereth, F.J.H., 1966. Some Chemical Observations on Post-Glacial Lake Sediments. Philosophical Transactions of the Royal Society of London. Series B, Biological Sciences, 250(765), 165-213.

Magny, M., Bégeot, C., 2004. Hydrological changes in the European midlatitudes associated with freshwater outbursts from Lake Agassiz during the Younger Dryas event and the early Holocene. Quaternary Research, 61(2), 181-192.

Magny, M., Miramont, C., Sivan, O., 2002. Assessment of the impact of climate and anthropogenic factors on Holocene Mediterranean vegetation in Europe on the basis of palaeohydrological records. Paleogeography, Palaeoclimatology, Palaeoecology, 186(1-2), 47-59.

Marret, F., Turon, J.-L., 1994. Paleohydrology and paleoclimatology off Northwest Africa during the last glacial-interglacial transition and the Holocene: Palynological evidences. Marine Geology, 118(1-2), 107-117.

Martín-Puertas, C., Valero-Garcés, B.L., Mata, M.P., González-Sampériz, P., Bao, R., Moreno, A., Stefanova, V., 2008. Arid and humid phases in southern Spain 
during the last 4000 years: the Zonar Lake record, Cordoba. The Holocene, 18(6), 907-921.

Martínez-Peña, M.B., Pocoví, A., 1984. Significado tectónico del peculiar relieve del Sinclinal de Estopiñán (Prepirineo de Huesca). In: S.G.d. España (Editor), I Congreso Español de Geología, Segovia (Spain), pp. 199-206.

Martinson, D.G., Pisias, N.G., Hays, J.D., Imbrie, J., Moore, T.C., Shackleton, N.J., 1987. Age dating and the orbital theory of the ice ages: Development of a highresolution 0 to 300,000-year chronostratigraphy. Quaternary Research, 27(1), 129.

Martrat, B., Grimalt, J.O., Lopez-Martinez, C., Cacho, I., Sierro, F.J., Flores, J.A., Zahn, R., Canals, M., Curtis, J.H., Hodell, D.A., 2004. Abrupt Temperature Changes in the Western Mediterranean over the past 250,000 Years. Science, $306,1762-1765$

Martrat, B., Grimalt, J.O., Shackleton, N.J., de Abreu, L., Hutterli, M.A., Stocker, T.F., 2007. Four Climate Cycles of Recurring Deep and Surface Water Destabilizations on the Iberian Margin. Science, 317(5837), 502-507.

Meyers, P.A., Lallier-Vergès, E., 1999. Lacustrine sedimentary organic matter records of Late Quaternary paleoclimates. Journal of Paleolimnology, 21, 345-372.

Meyers, P.A., Teranes, J.L., 2001. Sediment organic matter. In: W.M. Last, J.P. Smol (Editors), Tracking environmental change using lake sediments. Volume 2: Physical and Geochemical Methods. Kluwer Academic Publishers, Dordrecht, The Netherlands, pp. 239-269.

Montserrat-Martí, J., 1992. Evolución glaciar y postglaciar del clima y la vegetación en la vertiente sur del Pirineo: estudio palinológico. Monografías del Instituto Pirenaico de Ecología-CSIC, Zaragoza, 147 pp. 
Morellón, M., Valero-Garcés, B., Moreno, A., González-Sampériz, P., Mata, P., Romero, O., Maestro, M., Navas, A., 2008. Holocene palaeohydrology and climate variability in Northeastern Spain: The sedimentary record of Lake Estanya (Pre-Pyrenean range). Quaternary International, 181, 15-31.

Morellón, M., Valero-Garcés, B.L., Anselmetti, F., Ariztegui, D., Schnellmann, M., Moreno, A., Mata, P., Rico, M., Corella, J.P., 2009. Late Quaternary deposition and facies model for karstic Lake Estanya (NE Spain). Sedimentology, doi: 10.1111/j.1365-3091.2008.01044.x.

Morellón, M., Valero-Garcés, B., González-Sampériz, P., Vegas-Vilarrúbia, T., Rubio, E., Rieradevall, M., Delgado-Huertas, A., Mata, P., Romero, Ó., Engstrom, D.R., López-Vicente, M., Navas, A., Soto, J., in press. Climate changes and human activities recorded in the sediments of Lake Estanya (NE Spain) during the Medieval Warm Period and Little Ice Age. Journal of Paleolimnology.

Moreno, A., Cacho, I., Canals, M., Grimalt, J.O., Sánchez-Goñi, M.F., Shackleton, N., Sierro, F.J., 2005. Links between marine and atmospheric processes oscillating on a millennial time-scale. A multi-proxy study of the last 50,000 yr from the Alboran Sea (Western Mediterranean Sea). Quaternary Science Reviews, 24(1415), 1623-1636.

Moreno, A., Valero-Garcés, B.L., González-Sampériz, P., Rico, M., 2008. Flood response to rainfall variability during the last 2000 years inferred from the Taravilla Lake record (Central Iberian Range, Spain). Journal of Paleolimnology, 40(3), 943-961.

Moreno, A., Valero-Garcés, B.L., Jiménez-Sánchez, M., Domínguez, M.J., Mata, P., Navas, A., González-Sampériz, P., Stoll, H., Farias, P., Morellón, M., Corella, 
J.P., Rico, M., in press. The last deglaciation in the Picos de Europa National Park (Cantabrian Mountains, Northern Spain). Journal of Quaternary Science.

Muller, J., Kylander, M., Martínez-Cortizas, A., Wüst, R.A.J., Weiss, D., Blake, K., Coles, B., García-Sanchez, R., 2008. The use of principle component analyses in characterising trace and major elemental distribution in a $55 \mathrm{kyr}$ peat deposit in tropical Australia: Implications to paleoclimate. Geochimica et Cosmochimica Acta, 72(2), 449-463.

Müller, P.J., Schneider, R., 1993. An automated leaching method for the determination of opal in sediments and particulate matter. Deep-Sea Research I, 40(3), 425444.

Naughton, F., Sánchez Goñi, M.F., Desprat, S., Turon, J.L., Duprat, J., Malaizé, B., Joli, C., Cortijo, E., Drago, T., Freitas, M.C., 2007. Present-day and past (last 25000 years) marine pollen signal off western Iberia. Marine Micropaleontology, 62(2), 91-114.

Ninyerola, M., Pons, X., Roure, J.M., 2005. Atlas Climático Digital de la Península Ibérica. Metodología y aplicaciones en bioclimatología y geobotánica. Universidad Autónoma de Barcelona, Bellaterra, Spain.

Oldfield, F., Crooks, P.R.J., Harkness, D.D., Petterson, G., 1997. AMS radiocarbon dating of organic fractions from varved lake sediments: an empirical test of reliability. Journal of Paleolimnology, 18(1), 87-91.

Ortiz, J.E., Torres, T., Delgado, A., Julià, R., Lucini, M., Llamas, F.J., Reyes, E., Soler, V., Valle, M., 2004. The palaeoenvironmental and palaeohydrological evolution of Padul Peat Bog (Granada, Spain) over one million years, from elemental, isotopic and molecular organic geochemical proxies. Organic Geochemistry, 35, 1243-1260. 
Peñalba, M.C., Arnold, M., Guiot, J., Duplessy, J.-C., de Beaulieu, J.-L., 1997. Termination of the Last Glaciation in the Iberian Peninsula Inferred from the Pollen Sequence of Quintanar de la Sierra. Quaternary Research, 48(2), 205-214. Pérez-Obiol, R., Julià, R., 1994. Climatic Change on the Iberian Peninsula Recorded in a 30,000-Yr Pollen Record from Lake Banyoles. Quaternary Research, 41(1), $91-98$

Pla, S., Catalán, J., 2005. Chrysophyte cysts from lake sediments reveal the submillennial winter/spring climate variability in the northwestern Mediterranean region throughout the Holocene. Climate dynamics, 24, 263-278.

Pons, A., Reille, M., 1988. The holocene and upper pleistocene pollen record from Padul (Granada, Spain): A new study. Palaeogeography, Palaeoclimatology, Palaeoecology, 66(3-4), 243-263.

Prentice, I.C., Webb, T., 1998. BIOME 6000: reconstructing global mid-Holocene vegetation patterns from palaeoecological records. Journal of Biogeography, 25(6), 997-1005.

Qin, B., Harrison, S.P., Kutzbach, J.E., 1998. Evaluation of modelled regional water balance using lake status data: a comparison of 6 ka simulations with the NCAR CCM. Quaternary Science Reviews, 17(6-7), 535-548.

Ramil-Rego, P., 1993. Evolución climática e historia de la vegetación durante el Pleistoceno Superior y el Holoceno en las regiones montañosas del NW ibérico. In: A. Pérez Alberti, L. Guitián, P. Ramil-Rego (Editors), La evolución del paisaje en las montañas del entorno de los Caminos Jacobeos. Xunta de Galicia, pp. 25-60.

Ramstein, G., Kageyama, M., Guiot, J., Wu, H., Hély, C., Krinner, G., Brewer, S., 2007. How cold was Europe at the Last Glacial Maximum? A synthesis of the 
progress achieved since the first PMIP model-data comparison. Clim. Past, 3(2), 331-339.

Rasmussen, S.O., Seierstad, I.K., Andersen, K.K., Bigler, M., Dahl-Jensen, D., Johnsen, S.J., 2008. Synchronization of the NGRIP, GRIP, and GISP2 ice cores across MIS 2 and palaeoclimatic implications. Quaternary Science Reviews, 27(1-2), $18-28$.

Reed, J.M., 1998. Diatom preservation in the recent sediment record of Spanish saline lakes: implications for palaeoclimate study. Journal of Paleolimnology, 19(2), 129-137.

Reed, J.M., Stevenson, A.C., Juggins, S., 2001. A multi-proxy record of Holocene climatic change in southwestern Spain: the Laguna de Medina, Cadiz. The Holocene, 11(6), 707-719.

Reimer, P.J., Baillie, M.G.L., Bard, E., Bayliss, A., Beck, J.W., Bertrand, C.J.H., Blackwell, P.G., Buck, C.E., Burr, G.S., Cutler, K.B., Damon, P.E., Edwards, R.L., Fairbanks, R.G., Friedrich, M., Guilderson, T.P., Hogg, A.G., Hughen, K.A., Kromer, B., McCormac, G., Manning, S., Ramsey, C.B., Reimer, R.W., Remmele, S., Southon, J.R., Stuiver, M., Talamo, S., Taylor, F.W., van der Plicht, J., Weyhenmeyer, C.E., 2004. IntCal04 terrestrial radiocarbon age calibration, 0-26 Cal Kyr BP. Radiocarbon, 46(3), 1029-1058.

Rico, M.T., 2004. Las paleocrecidas en la cuenca media del Río Segre durante el Pleistoceno superior-Holoceno: registros morfosedimentarios $\mathrm{y}$ análisis hidrológico. PhD Thesis, University of Zaragoza, Zaragoza, Spain.

Richter, T.O., Van der Gaast, S.J., Koster, B., Vaars, A.J., Gieles, R., De Stigter, H.C., De Haas, H., Van Weering, T.C.E., 2006. The Avaatech XRF Core Scanner: technical description and applications to NE Atlantic sediments. In: R.G. 
Rothwell (Editor), New Techniques in Sediment Core Analysis. Geological Society, London, Special Publications. The Geological Society of London, pp. $39-50$.

Riera, S., López-Sáez, J.A., Julià, R., 2006. Lake responses to historical land use changes in northern Spain: The contribution of non-pollen palynomorphs in a multiproxy study. Review of Palaeobotany and Palynology, 141(1-2), 127-137.

Riera, S., Wansard, R., Julià, R., 2004. 2000-year environmental history of a karstic lake in the Mediterranean Pre-Pyrenees: the Estanya lakes (Spain). Catena, 55, 293-324.

Rivas-Martínez, S., 1982. Étages bioclimatiques, secteurs chorologiques et séries de végetation de l’Espagne méditerranéenne. Ecologia Mediterranea, VIII(1-2), $275-288$

Roberts, N., Reed, J.M., Leng, M.J., Kuzucuoglu, C., Fontugne, M., Bertaux, J., Woldring, H., Bottema, S., Black, S., Hunt, E., Karabiyikoglu, M., 2001. The tempo of Holocene climatic change in the eastern Mediterranean region: new high-resolution crater-lake sediment data from central Turkey. The Holocene, 11(6), 721-736.

Rossignol-Strick, M., 1999. The Holocene climatic optimum and pollen records of sapropel 1 in the eastern Mediterranean, 9000-6000 BP. Quaternary Science Reviews, 18(4-5), 515-530.

Roucoux, K.H., de Abreu, L., Shackleton, N.J., Tzedakis, P.C., 2005. The response of NW Iberian vegetation to North Atlantic climate oscillations during the last 65 kyr. Quaternary Science Reviews, 24(14-15), 1637-1653.

Roucoux, K.H., Shackleton, N.J., de Abreu, L., Schönfeld, J., Tzedakis, P.C., 2001. Combined Marine Proxy and Pollen Analyses Reveal Rapid Iberian Vegetation 
Response to North Atlantic Millennial-Scale Climate Oscillations. Quaternary Research, 56(1), 128-132.

Sadori, L., Narcisi, B., 2001. The Postglacial record of environmental history from Lago di Pergusa, Sicily. The Holocene, 11(6), 655-671.

Sánchez-Goñi, M.F., Cacho, I., Turon, J.L., Guiot, J., Sierro, F.J., Peypouquet, J.P., Grimalt, J.O., Shackleton, N.J., 2002. Synchroneity between marine and terrestrial responses to millennial scale climatic variability during the last glacial period in the Mediterranean region. Climate dynamics, 19, 95-105.

Sánchez Goñi, M.F., Eynaud, F., Turon, J.L., Shackleton, N.J., 1999. High resolution palynological record off the Iberian margin: direct land-sea correlation for the Last Interglacial complex. Earth and Planetary Science Letters, 171(1), 123-137.

Sancho-Marcén, C., 1988. El Polje de Saganta (Sierras Exteriores pirenaicas, prov. de Huesca). Cuaternario y Geomorfología, 2(1-4), 107-113.

Sancho, C., Peña, J.L., Lewis, C., McDonald, E., Rhodes, E., 2003. Preliminary dating of glacial and fluvial deposits in the Cinca River Valley (NE Spain): chronological evidences for the Glacial Maximum in the Pyrenees? In: M.B. Ruiz et al. (Editors), Quaternary climatic changes and environmental crises in the Mediterranean region. Universidad de Alcalá -Ministerio de Ciencia y Tecnología -INQUA, pp. 169-173.

Sancho, C., Peña, J.L., Muñoz, A., Benito, G., McDonald, E., Rhodes, E.J., Longares, L.A., 2007. Holocene alluvial morphopedosedimentary record and environmental changes in the Bardenas Reales Natural Park (NE Spain). CATENA, doi:10.1016/j.catena.2007.09.011 
Schaller, T., Christoph Moor, H., Wehrli, B., 1997. Sedimentary profiles of Fe, Mn, V, $\mathrm{Cr}$, As and Mo as indicators of benthic redox conditions in Baldeggersee. Aquatic Science, 59, 345-361.

Schreiber, B.C., Tabakh, M.E., 2000. Deposition and early alteration of evaporites. Sedimentology, 47(s1), 215-238.

Schutt, B., 1998. Reconstruction of palaeoenvironmental conditions by investigation of Holocene playa sediments in the Ebro Basin, Spain: preliminary results. Geomorphology, 23(2-4), 273-283.

Sierro, F.J., Hodell, D.A., Curtis, J.H., Flores, J.A., Reguera, I., Colmenero-Hidalgo, E., Bárcena, M.A., Grimalt, J.O., Cacho, I., Frigola, J., Canals, M., 2005. Impact of iceberg melting on Mediterranean thermohaline circulation during Heinrich events. Paleoceanography, 20(PA2019), doi:10.1029/2004PA001051.

Stevenson, A.C., 2000. The Holocene forest history of the Montes Universales, Teruel, Spain. The Holocene, 10(5), 603-610.

Tracey, B., Lee, N., Card, V., 1996. Sediment indicators of meromixis: comparison of laminations, diatoms, and sediment chemistry in Brownie Lake, Minneapolis, USA Journal of Paleolimnology, 15, 129-132.

Tzedakis, P.C., 1993. Long-term tree populations in northwest Greece through multiple Quaternary climatic cycles. Nature, 364(6436), 437-440.

Tzedakis, P.C., 2007. Seven ambiguities in the Mediterranean palaeoenvironmental narrative. Quaternary Science Reviews, 26(17-18), 2042-2066.

Valero-Garcés, B., Delgado-Huertas, A., Navas, A., Machín, J., González-Sampériz, P., Kelts, K., 2000a. Quaternary palaeohydrological evolution of a playa lake: Salada Mediana, central Ebro Basin, Spain. Sedimentology, 47, 1135-1156. 
Valero-Garcés, B., González-Sampériz, P., Delgado-Huertas, A., Navas, A., Machín, J., Kelts, K., 2000b. Lateglacial and Late Holocene environmental and vegetational change in Salada Mediana, central Ebro Basin, Spain. Quaternary International, 73/74, 29-46.

Valero-Garcés, B., González-Sampériz, P., Navas, A., Machín, J., Delgado-Huertas, A., Peña-Monné, J.L., Sancho-Marcén, C., Stevenson, T., Davis, B., 2004. Palaeohydrological fluctuations and steppe vegetation during the Last Glacial Maximum in the central Ebro valley (NE Spain). Quaternary International, $122(1), 43-55$.

Valero-Garcés, B.L., Kelts, K.R., 1995. A sedimentary facies model for perennial and meromictic saline lakes: Holocene Medicine Lake Basin, South Dakota, USA. Journal of Paleolimnology, 14(2), 123-149.

Valero Garcés, B.L., Moreno, A., Navas, A., Mata, P., Machín, J., Delgado Huertas, A., González Sampériz, P., Schwalb, A., Morellón, M., Cheng, H., Edwards, R.L., 2008. The Taravilla lake and tufa deposits (Central Iberian Range, Spain) as palaeohydrological and palaeoclimatic indicators. Palaeogeography, Palaeoclimatology, Palaeoecology, 259(2-3), 136-156.

van der Knaap, W.O., van Leeuwen, J.F.N., 1995. Holocene vegetation succession and degradation as responses to climatic change and human activity in the Serra de Estrela, Portugal. Review of Palaeobotany and Palynology, 89(3-4), 153-211.

van der Knaap, W.O., van Leeuwen, J.F.N., 1997. Late Glacial and early Holocene vegetation succession, altitudinal vegetation zonation, and climatic change in the Serra da Estrela, Portugal. Review of Palaeobotany and Palynology, 97(3-4), 239-285. 
Vegas, J., Pérez-González, A., Ruiz Zapata, B., Gil-García, M.J., Dorado, M., Valdeolmillos, A., López-García, M.J., 2003. The GS-1/Younger Dryas Event in the Laguna Grande lacustrine record. Lateglacial-Holocene transition in the NW Iberian Range, Spain. In: B. Valero-Garcés (Editor), Limnogeology in Spain: a tribute to Kerry Kelts. Biblioteca de Ciencias. C.S.I.C., Madrid, pp. 284-304.

Villa, I., Gracia, M.L., 2004. Estudio hidrogeológico del sinclinal de Estopiñán (Huesca). XXXVIII CHIS, Confederación Hidrográfica del Ebro, Zaragoza.

Wansard, G., 1996. Quantification of paleotemperature changes during isotopic stage 2 in the La Draga continental sequence (NE Spain) based on the $\mathrm{Mg} / \mathrm{Ca}$ ratio of freshwater ostracods. Quaternary Science Reviews, 15, 237-245.

Weninger, B., Jöris, O., 2004. Glacial Radiocarbon Calibration. The CalPal Program. In: T. Higham, C.B. Ramsey, C. Owen (Editors), Radiocarbon and Archaeology. Fourth International Symposium, Oxford 2002.

Wu, H., Guiot, J., Brewer, S., Guo, Z., 2007. Climatic changes in Eurasia and Africa at the last glacial maximum and mid-Holocene: reconstruction from pollen data using inverse vegetation modelling. Climate Dynamics, 29(2), 211-229.

Y11, E.-I., Pérez-Obiol, R., Pantaleón-Cano, J., Roure, J.M., 1997. Palynological Evidence for Climatic Change and Human Activity during the Holocene on Minorca (Balearic Islands). Quaternary Research, 48(3), 339-347. 
TABLE CAPTIONS

\begin{tabular}{|c|c|c|c|c|c|c|c|c|c|c|c|c|c|}
\hline \multirow{2}{*}{$\begin{array}{c}\text { Water } \\
\text { depth } \\
\text { (m) }\end{array}$} & \multirow{2}{*}{$\begin{array}{c}\text { Temperature } \\
\left({ }^{\circ} \mathbf{C}\right)\end{array}$} & \multirow{2}{*}{$\begin{array}{c}\text { Conductivity } \\
(\mu \mathrm{S} \mathrm{cm}-1)\end{array}$} & \multirow[t]{2}{*}{ pH } & \multirow{2}{*}{$\begin{array}{c}\text { Oxygen } \\
\text { saturation } \\
(\%)\end{array}$} & Mg & $\mathbf{K}$ & $\mathrm{Na}$ & $\mathrm{Sr}$ & $\mathbf{L i}$ & $\mathrm{Ca}$ & $\mathrm{HCO}_{3}$ & $\mathrm{Cl}$ & $\mathrm{SO}_{4}$ \\
\hline & & & & & \multicolumn{9}{|c|}{$\left(\mathrm{mg} \mathrm{l}^{-1}\right)$} \\
\hline 0 & 24.3 & 3440 & 7. & 65.8 & 132 & 14.2 & 133 & 7.8 & 0.16 & 440 & 1.37 & 6.6 & 1813.1 \\
\hline 16 & 5.1 & 3330 & 7.4 & 0.0 & 127 & 14 & 124 & 7.1 & 0.15 & 402 & 1.49 & 6.3 & - \\
\hline
\end{tabular}

Table 1. Physical and chemical properties of Lake Estanya (SE subbasin) at the lake surface and $16 \mathrm{~m}$ water depth for 24/6/2005 (summer stratification season).

\begin{tabular}{|c|c|c|c|c|c|c|}
\hline Core & $\begin{array}{c}\text { Comp. } \\
\text { depth } \\
\text { (cm) } \\
\end{array}$ & $\begin{array}{c}\text { Sedimentary } \\
\text { units }\end{array}$ & $\begin{array}{c}\text { Laboratory } \\
\text { code }\end{array}$ & $\begin{array}{l}\text { Type of } \\
\text { material }\end{array}$ & $\begin{array}{c}{ }^{14} C A M S \text { age } \\
(y r B P)\end{array}$ & $\begin{array}{c}\text { Calculated } \\
\text { reservoir effect } \\
\text { (yr.) }\end{array}$ \\
\hline \multirow{4}{*}{$1 \mathrm{~A}$} & \multirow{2}{*}{35.5} & \multirow{2}{*}{ I } & & $\begin{array}{l}\text { Phragmites } \\
\text { stem }\end{array}$ & $155 \pm 30$ & \\
\hline & & & Poz - 24760 & $\begin{array}{l}\text { Bulk organic } \\
\text { matter }\end{array}$ & $740 \pm 30$ & $585 \pm 60$ \\
\hline & \multirow[b]{2}{*}{439.5} & \multirow[b]{2}{*}{ IV } & Poz - 9891 & wood fragment & $8510 \pm 50$ & \\
\hline & & & Poz - 23670 & $\begin{array}{c}\text { bulk organic } \\
\text { matter }\end{array}$ & $9330 \pm 50$ & $820 \pm 100$ \\
\hline \multirow{2}{*}{$5 \mathrm{~A}$} & \multirow{2}{*}{890.6} & \multirow{2}{*}{ VII } & Poz - 17194 & wood fragment & $16100 \pm 80$ & (reworked) \\
\hline & & & Poz - 23671 & $\begin{array}{l}\text { bulk organic } \\
\text { matter }\end{array}$ & $15160 \pm 90$ & $(*)$ \\
\hline
\end{tabular}

Table 2. Comparison between pairs of radiocarbon dates obtained after analyzing bulk organic sediment and terrestrial plant macroremains at the same core depth intervals. Estimated reservoir effect is indicated for each of the bulk organic matter samples. $\left(^{*}\right)$ No reservoir effect could be calculated for the older pair because of the reworked nature of the organic macroremain. 


\begin{tabular}{|c|c|c|c|c|c|c|}
\hline $\begin{array}{c}\text { Comp } \\
\text { depth } \\
(\mathrm{cm})\end{array}$ & $\begin{array}{c}\text { Sedimentary } \\
\text { units }\end{array}$ & $\begin{array}{c}\text { Laboratory } \\
\text { code }\end{array}$ & $\begin{array}{c}\text { Type of } \\
\text { material }\end{array}$ & $\begin{array}{c}A M S{ }^{14} C \text { age } \\
(y r B P)\end{array}$ & $\begin{array}{c}\text { Corrected } \\
A M S^{14} C \text { age } \\
(y r B P)\end{array}$ & $\begin{array}{c}\text { Calibrated } \\
\text { age } \\
\text { (cal yrs BP) } \\
\text { (range 2 } \sigma)\end{array}$ \\
\hline \multicolumn{7}{|c|}{ CORE 1A } \\
\hline 35.5 & I & Poz - 24749 & $\begin{array}{l}\text { Phragmites } \\
\text { stem fragment }\end{array}$ & $155 \pm 30$ & $155 \pm 30$ & $160 \pm 100$ \\
\hline 61.5 & I & Poz - 12245 & $\begin{array}{l}\text { Terrestrial plant } \\
\text { remains and } \\
\text { charcoal }\end{array}$ & $405 \pm 30$ & $405 \pm 30$ & $460 \pm 60$ \\
\hline 177 & II & Poz - 12246 & $\begin{array}{l}\text { Terrestrial plant } \\
\text { remains }\end{array}$ & $895 \pm 35$ & $895 \pm 35$ & $840 \pm 60$ \\
\hline 196.5 & II & Poz - 15972 & $\begin{array}{l}\text { bulk organic } \\
\text { matter }\end{array}$ & $2120 \pm 30$ & $1300 \pm 130$ & $1210 \pm 130$ \\
\hline 240 & III & Poz - 12247 & Salix leave & $3315 \pm 35$ & $3315 \pm 35$ & $3550 \pm 50$ \\
\hline 337.5 & III & Poz - 12248 & $\begin{array}{l}\text { Gramineae } \\
\text { seed }\end{array}$ & $5310 \pm 60$ & $5310 \pm 60$ & $6100 \pm 90$ \\
\hline 350 & III & Poz - 15973 & $\begin{array}{l}\text { bulk organic } \\
\text { matter }\end{array}$ & $6230 \pm 40$ & $5410 \pm 140$ & $6180 \pm 150$ \\
\hline 390 & III & Poz - 15974 & $\begin{array}{l}\text { bulk organic } \\
\text { matter }\end{array}$ & $8550 \pm 50$ & $7730 \pm 150$ & $8600 \pm 180$ \\
\hline 439.5 & IV & Poz - 9891 & wood fragment & $8510 \pm 50$ & $8510 \pm 50$ & $9510 \pm 30$ \\
\hline
\end{tabular}

\section{CORE 5A}

\begin{tabular}{|c|c|c|c|c|c|c|}
\hline 478.6 & IV & Poz - 17190 & $\begin{array}{c}\text { plant } \\
\text { macroremain }\end{array}$ & $8830 \pm 50$ & $8830 \pm 50$ & $9940 \pm 150$ \\
\hline 549.6 & IV & Poz - 17191 & $\begin{array}{l}\text { bulk organic } \\
\text { matter }\end{array}$ & $10680 \pm 60$ & $9860 \pm 160$ & $11380 \pm 270$ \\
\hline 614.6 & V & Poz - 20138 & $\begin{array}{l}\text { bulk organic } \\
\text { matter }\end{array}$ & $11820 \pm 60$ & $11000 \pm 160$ & $12980 \pm 120$ \\
\hline 659.6 & VI & Poz - 17192 & macroremain & $11710 \pm 60$ & $11710 \pm 60$ & $13570 \pm 90$ \\
\hline 680.1 & VI & Poz - 20139 & $\begin{array}{l}\text { bulk organic } \\
\text { matter }\end{array}$ & $12700 \pm 70$ & $11880 \pm 170$ & $13730 \pm 190$ \\
\hline 704.1 & VI & Poz - 20067 & $\begin{array}{l}\text { bulk organic } \\
\text { matter }\end{array}$ & $13280 \pm 60$ & $12460 \pm 160$ & $14550 \pm 300$ \\
\hline 767.6 & VI & Poz - 17283 & $\begin{array}{l}\text { bulk organic } \\
\text { matter }\end{array}$ & $14830 \pm 90$ & $14010 \pm 190$ & $16730 \pm 270$ \\
\hline 957.5 & VII & Poz - 20140 & plant remains & $15130 \pm 100$ & $15130 \pm 100$ & $18420 \pm 220$ \\
\hline
\end{tabular}

Table 3. Radiocarbon dates used for the construction of the age model for the Lake Estanya sequence. A correction of $820 \pm 100{ }^{14} \mathrm{C}$ years was applied to bulk sediment 
samples from units II to VI. Corrected dates were calibrated using CALPAL_A software (Weninger and Jöris, 2004) and the INTCAL04 curve (Reimer et al., 2004); and the median of the $95.4 \%$ of the distribution ( $2 \sigma$ probability interval) was selected.

\begin{tabular}{|c|c|c|c|}
\hline Facies & Sedimentological features & $\begin{array}{l}\text { Depositional } \\
\text { subenvironment }\end{array}$ & $\begin{array}{l}\text { Lake } \\
\text { level }\end{array}$ \\
\hline \multicolumn{4}{|c|}{ CLASTIC FACIES } \\
\hline 1 & Blackish, banded carbonate clayey silts & $\begin{array}{l}\text { Deep, monomictic, seasonally } \\
\text { stratified freshwater to brackish } \\
\text { lake }\end{array}$ & 9 \\
\hline \multirow[t]{2}{*}{2} & $\begin{array}{l}\text { Grey, banded to laminated Subfacies } 2.1 \\
\text { calcareous silts }\end{array}$ & $\begin{array}{l}\text { Deep, monomictic, seasonally } \\
\text { stratified, freshwater to brackish } \\
\text { lake }\end{array}$ & 9 \\
\hline & Subfacies 2.2 & Flood and/or turbiditic events & \\
\hline 3 & Black, massive to faintly laminated silty clay & Deep, dimictic, freshwater lake & 10 \\
\hline \multicolumn{4}{|c|}{ ORGANIC-RICH FACIES } \\
\hline 4 & $\begin{array}{l}\text { Brown, massive to faintly laminated sapropel } \\
\text { with gypsum }\end{array}$ & Shallow saline lake & 6 \\
\hline 5 & $\begin{array}{l}\text { Variegated finely laminated microbial mats } \\
\text { with aragonite and gypsum }\end{array}$ & $\begin{array}{l}\text { Moderately deep saline lake } \\
\text { with microbial mats }\end{array}$ & 7 \\
\hline \multicolumn{4}{|c|}{ CARBONATE-RICH FACIES } \\
\hline 6 & $\begin{array}{l}\text { Grey and mottled, massive carbonate silt with } \\
\text { plant remains and gypsum }\end{array}$ & $\begin{array}{l}\text { Ephemeral saline lake - mud } \\
\text { flat }\end{array}$ & 2 \\
\hline 7 & $\begin{array}{l}\text { Grey, banded to laminated carbonate-rich } \\
\text { silts }\end{array}$ & $\begin{array}{l}\text { Shallow, carbonate-producing } \\
\text { lake }\end{array}$ & 4 \\
\hline \multicolumn{4}{|c|}{ GYPSUM-RICH FACIES } \\
\hline 8 & $\begin{array}{l}\text { Variegated, finely laminated gypsum, } \\
\text { carbonates and clay }\end{array}$ & $\begin{array}{l}\text { Relatively deep, saline, } \\
\text { permanent lake }\end{array}$ & 5 \\
\hline 9 & $\begin{array}{l}\text { Variegated, banded gypsum, carbonates and } \\
\text { clay }\end{array}$ & Shallow saline lake & 3 \\
\hline 10 & Yellowish, massive, coarse-grained gypsum & $\begin{array}{l}\text { Ephemeral saline lake - mud } \\
\text { flat }\end{array}$ & 1 \\
\hline
\end{tabular}

Table 4. Main sedimentological and mineralogical features, inferred depositional environment and relative lake level estimation for the different facies and sub-facies defined for the Lake Estanya sedimentary sequence. Modified from Morellón et al. (2009). 
(A)

\begin{tabular}{lrrr}
\hline & \multicolumn{3}{c}{ Initial Eigenvalues } \\
\hline Component & Total & \% of Variance & \multicolumn{1}{c}{ Cumulative \% } \\
\hline 1 & 4.671 & 66.728 & 66.728 \\
2 & 1.495 & 21.360 & 88.089 \\
3 & 0.546 & 7.796 & 95.884
\end{tabular}

(B)

\begin{tabular}{lcc}
\hline & \multicolumn{2}{c}{ Component } \\
\hline & $\mathbf{1}$ & $\mathbf{2}$ \\
\hline $\mathbf{A l}$ & 0.988 & -0.099 \\
$\mathbf{S i}$ & 0.892 & 0.164 \\
$\mathbf{K}$ & 0.780 & 0.222 \\
$\mathbf{T i}$ & 0.657 & 0.396 \\
$\mathbf{C a}$ & 0.018 & -0.986 \\
$\mathbf{F e}$ & 0.321 & 0.670 \\
$\mathbf{S}$ & -0.221 & -0.228 \\
\hline
\end{tabular}

Table 5. Principal Component Analysis (PCA). (A) Eigenvalues for the 7 obtained components. The percentage of the variance explained by each axis is also indicated.

(B) Factorloads for each variable in the two main axes. 


\section{FIGURE CAPTIONS}

Figure 1. (A) Map of mean annual rainfall distribution in the Iberian Peninsula (Ninyerola et al., 2005). Location of the study area is indicated with a star. (B) Topographic and geological map of 'Balsas de Estanya' catchment area (see legend below). (C) Bathymetry of the main lake, Estanque Grande de Abajo with coring sites.

Figure 2. (A) Correlation between short core (0A) and longest cores (1A and 5A), retrieved in the deepest area of the SE sub-basin. Correlation between long cores $1 \mathrm{~A}$ and 5A was performed with high-resolution core-scan images, lithostratigraphy, density core logs $\left(\mathrm{g} / \mathrm{cm}^{3}\right)$, indicated by dotted lines; and Magnetic Susceptibility (MS) (SI units) core logs, represented by dashed lines. (B) Detail of correlation between short core 0A and uppermost part of core $1 \mathrm{~A}$ using of the percentage of organic matter and calcium carbonate and TOC and TIC values, respectively.

Figure 3. Composite sequence for Lake Estanya record. From left to right: Sedimentary units and corresponding subunits, core image, sedimentological profile and sequences, Magnetic Susceptibility (MS) (full range (thick line) and at the $0-8$ range (thin line), in SI units), whole sediment mineralogical content $(\mathrm{Qtz}=$ quartz, Phy $=$ phyllosilicates, $\mathrm{Cal}=$ calcite, $\mathrm{Do}=$ dolomite, $\mathrm{Gp}=$ gypsum $)(\%) ; \mathrm{TOC}=$ Total Organic Carbon $(\%) ; \mathrm{TN}$ $=$ Total Nitrogen $(\%)$; atomic $\mathrm{TOC} / \mathrm{TN}$ ratio; $\delta^{13} \mathrm{C}_{\text {org }}$ (per mil) (in organic matter), referred to VPDB standard; biogenic silica concentration (Bio $\mathrm{Si}$ ) (0 - 7.2\% range); diatom VA $=$ Valve Abundance $(5=$ high, $4=$ common, $3=$ low, $2=$ rare, $1=$ trace and $0=$ barren); inferred depositional environments for each unit; and interpreted relative lake level (0-10) evolution of the sequence based on sedimentary facies reconstruction.

Figure 4. (A) X-ray Fluorescence (XRF) data measured by the core scanner. Light element ( $\mathrm{Si}, \mathrm{Al}, \mathrm{K}, \mathrm{Ti}, \mathrm{Fe}, \mathrm{S}$ and $\mathrm{Ca}$ ) concentrations are expressed as element 
intensities. Variations of the two first eigenvectors (PCA1 and PCA2) scores against composite depth have also been plotted as synthesis of the FRX variables. Sedimentary units and subunits, core image and sedimentological profile are also indicated (see legend in figure 3). (B) Correlation plots of K, Ca, Fe (measured by the ICP-MS (ppm)) and S (measured by LECO analyzer) and the XRF Core Scanner (element intensities). Correlation lines, $\mathrm{r}^{2}$ and $\mathrm{p}$-values are shown.

Figure 5. Principal Components Analysis (PCA) projection of factor loadings for the XRay Fluorescence analyzed elements ( $\mathrm{Si}, \mathrm{Al}, \mathrm{K}, \mathrm{Ti}, \mathrm{Fe}, \mathrm{S}$ and $\mathrm{Ca}$ ) from Lake Estanya sequence. Dots represent the factorloads for every variable in the two main axes.

Figure 6. (A) Chronological model of the studied sequence based on mixed effect regression function (Heegaard et al., 2005) of $17 \mathrm{AMS}{ }^{14} \mathrm{C}$ dates (black dots) and 4 tie points (white dots). A reversal date is also represented (see "rejected dates" in the legend). The continuous line represents the age-depth function framed by dashed lines (error lines). Sedimentary units and limits of cores used for the composite sequence are also displayed at the right end. Sedimentary units are grouped according to their main sedimentary features, separated by horizontal dotted lines and represented with their corresponding Linear Sedimentation Rates (LSR). Horizontal grey bands represent intervals characterized by clastic-dominant facies. (B) Detail of the 4 tie points calculated for clastic dominant intervals (subunits III.2 and III.4) characterized by higher LSRs, inferred from radiocarbon dates analyzed in subunit III.4.

Figure 7. Lake level reconstruction of Lake Estanya for the last ca. 21000 cal yrs. BP compared with a suite of global and regional palaeoclimatic records. In the lower section, from bottom to top: division in the four main stages in the evolution of the lake system; sedimentary units; lake level reconstruction, based on sedimentary facies (vertical bands for each sub-unit, from 0 to 10 , see table 4 and figure 3); $\mathrm{AMS}{ }^{14} \mathrm{C}$ dates 
(cal yrs BP) and tie points (both with error bars), included in the age model; geochemically-based 'Clastic input' and 'Salinity' estimations, derived from PCA axis 1 and 2, respectively (original data is plotted in grey hairline, whereas smoothed data (running average, period $=10$ ) is represented with thicker lines); $\delta^{13} \mathrm{C}_{\mathrm{org}}$ (per mil) (in organic matter), referred to VPDB standard; and Biogenic silica concentrations (Bio Si) (0 - 7.2\% range).-sterile intervals.

In the upper section, from top to bottom: $\mathrm{N}$ GRIP Greenland ice core $\delta^{18} \mathrm{O}$ record (Rasmussen et al., 2008); summer (grey) and winter (black) insolation at $42^{\circ} \mathrm{N}$ (in $\mathrm{W} / \mathrm{m}^{2}$ ); Lake Banyoles mesophyte/steppe pollen taxa ratio (Pérez-Obiol and Julià, 1994); Potassium (K) content (\%) in Minorca drift sediments inferred from core MD992343 (3) (Frigola et al., 2008); and SST $\left({ }^{\circ} \mathrm{C}\right)$ in Alboran Sea inferred from core MD952043 (2) (Cacho et al., 2001).

Dotted vertical lines represent divisions between the 4 main stages in the evolution of the Lake Estanya basin, whereas dark and light grey vertical bands represent global climate events (from left to right: Younger Dryas (YD), Bölling/Allerød (B/A), Mystery Interval (MI), and Last Glacial Maximum (LGM). 


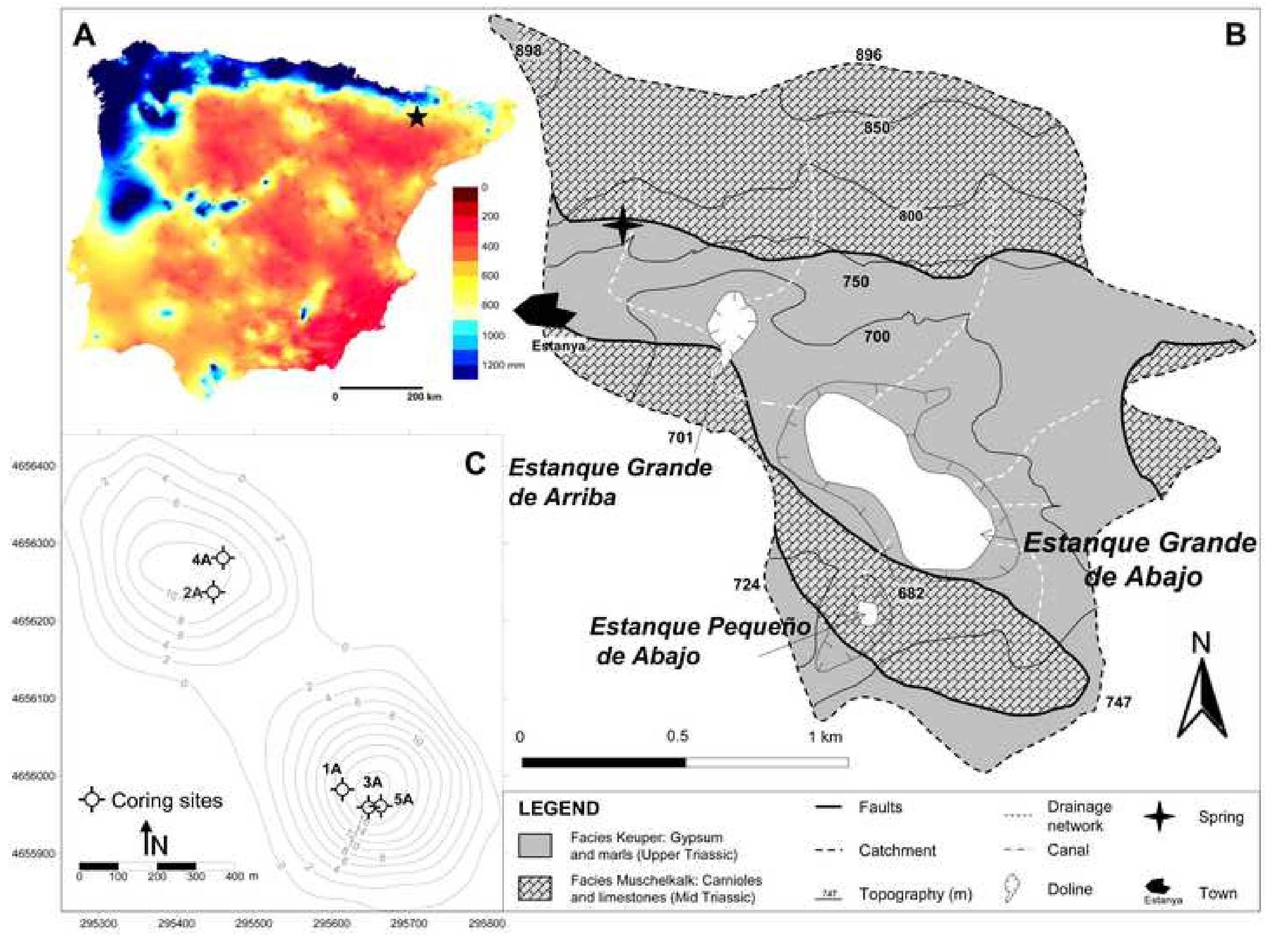




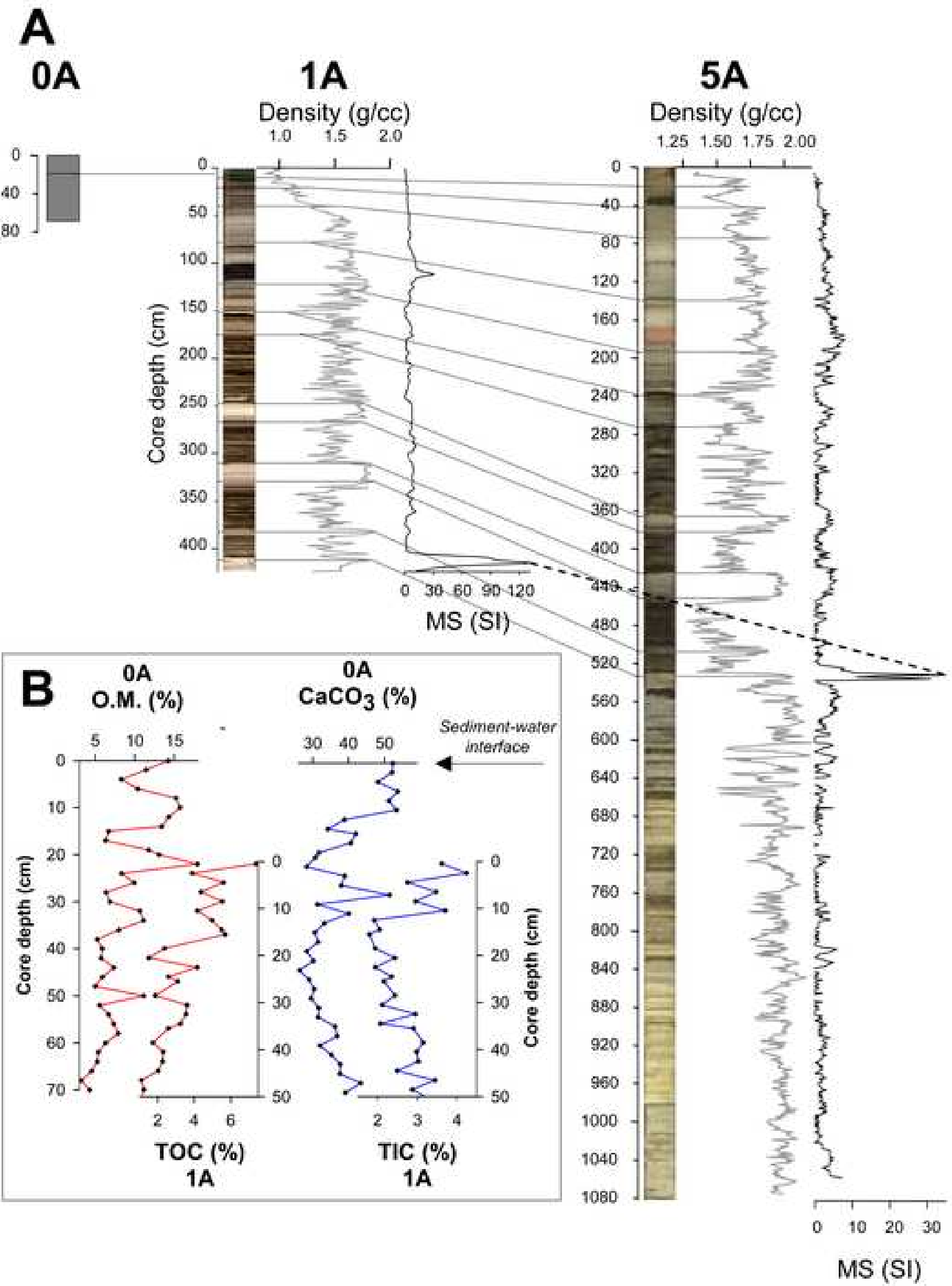




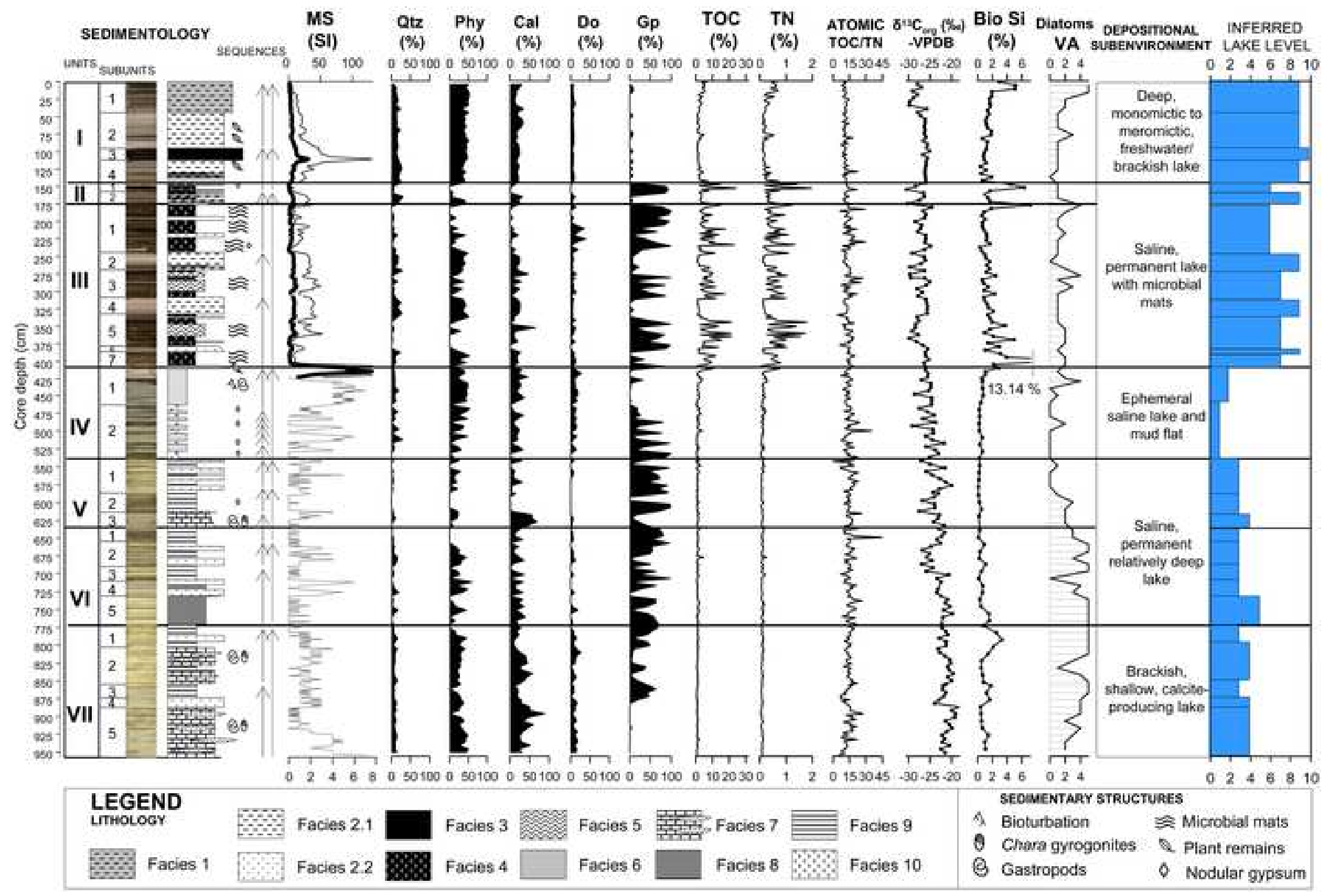


Click here to download high resolution image

A SEDIMENTOLogy Si (area) Al (area) K(area) Ti (area) Fe (area) S (area) Ca (area) PCA axis 1 PCA axis 2

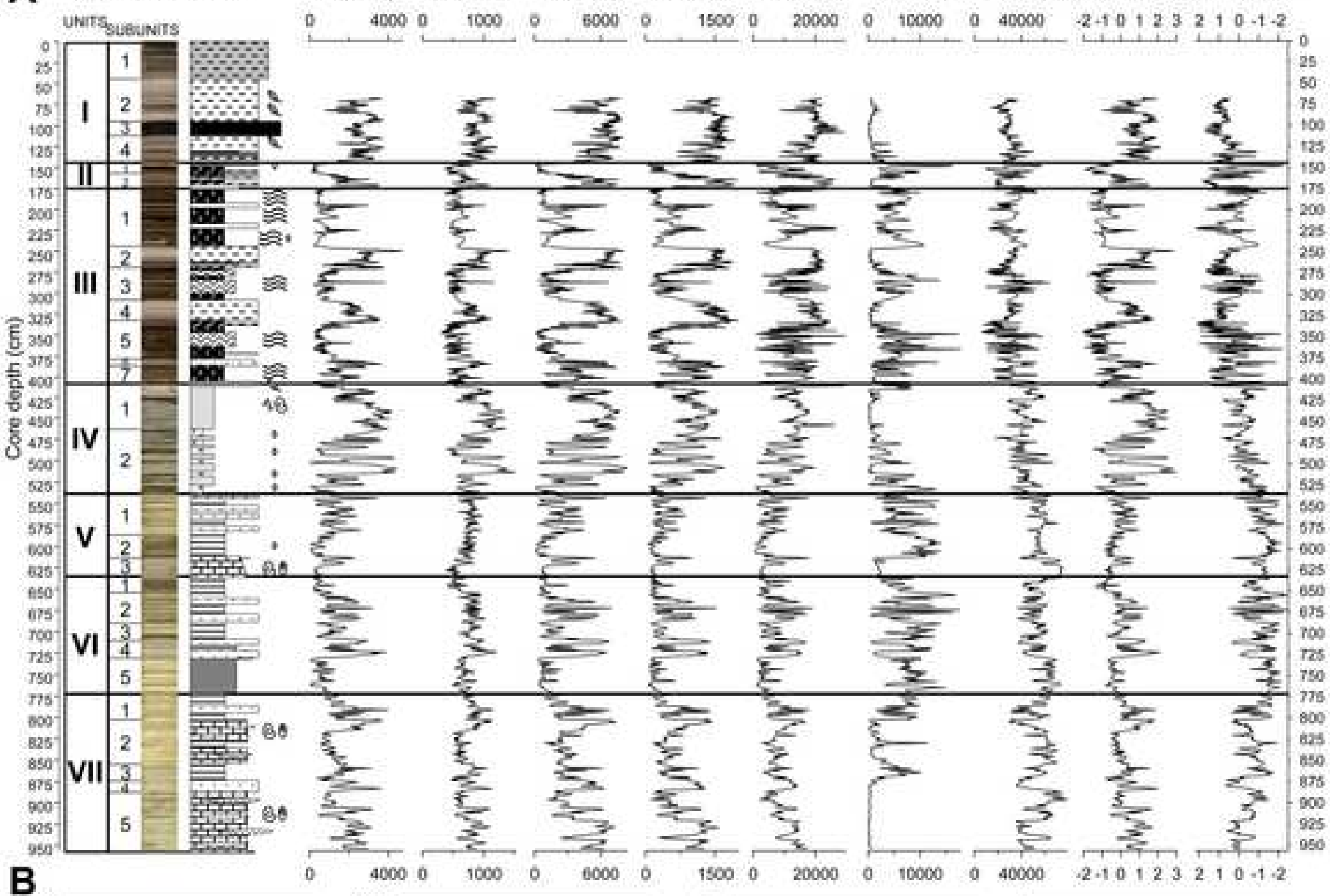

B
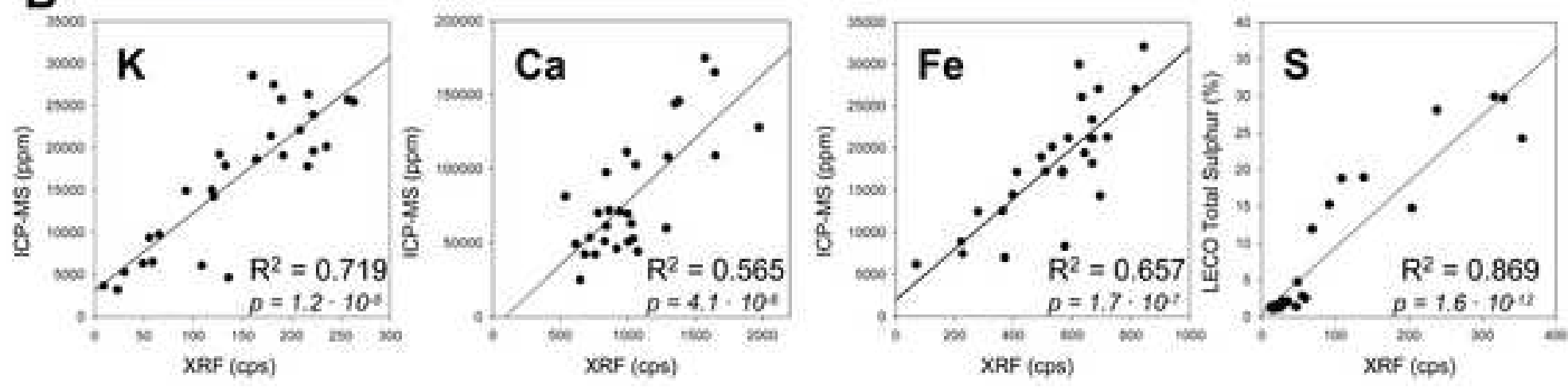


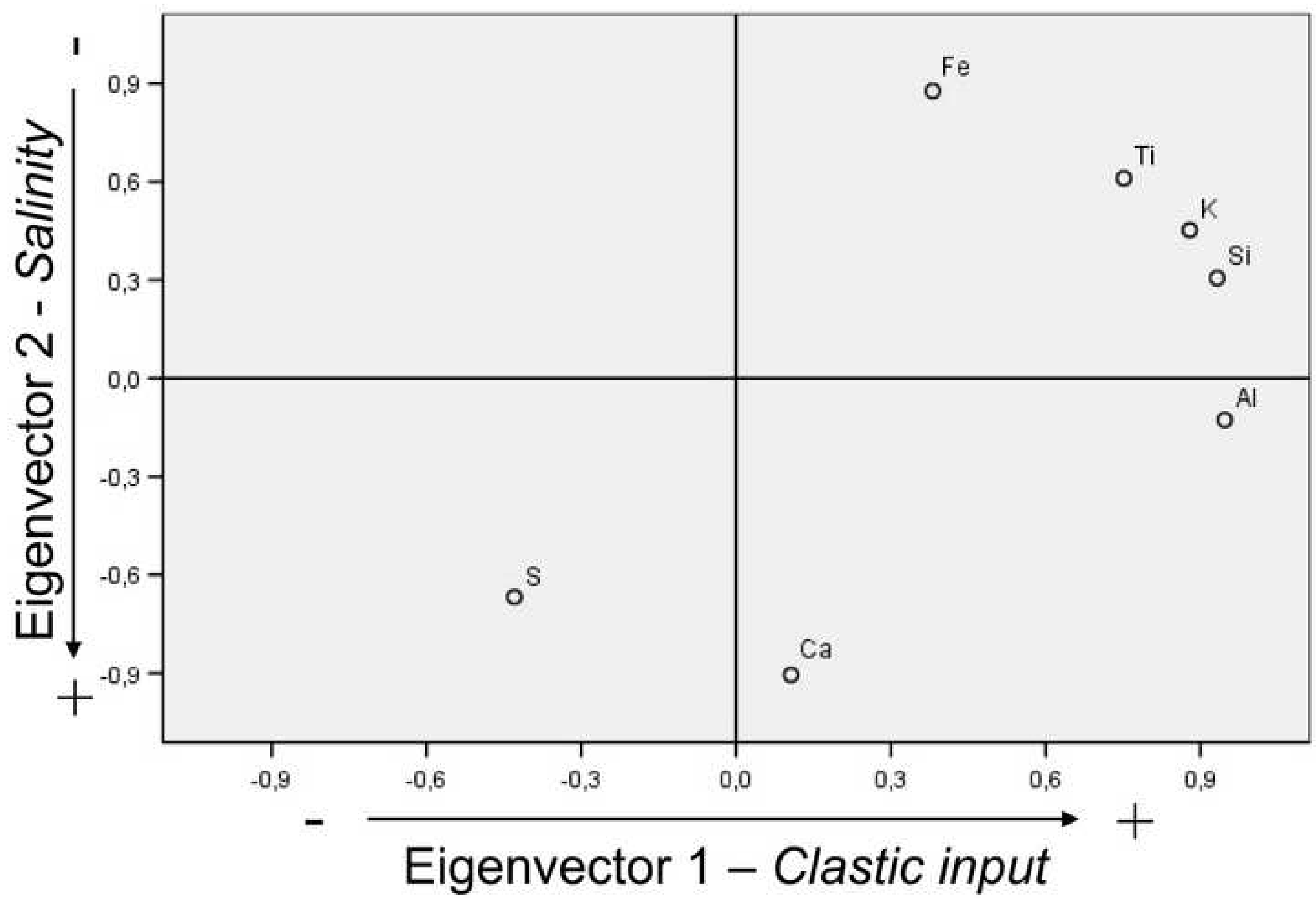




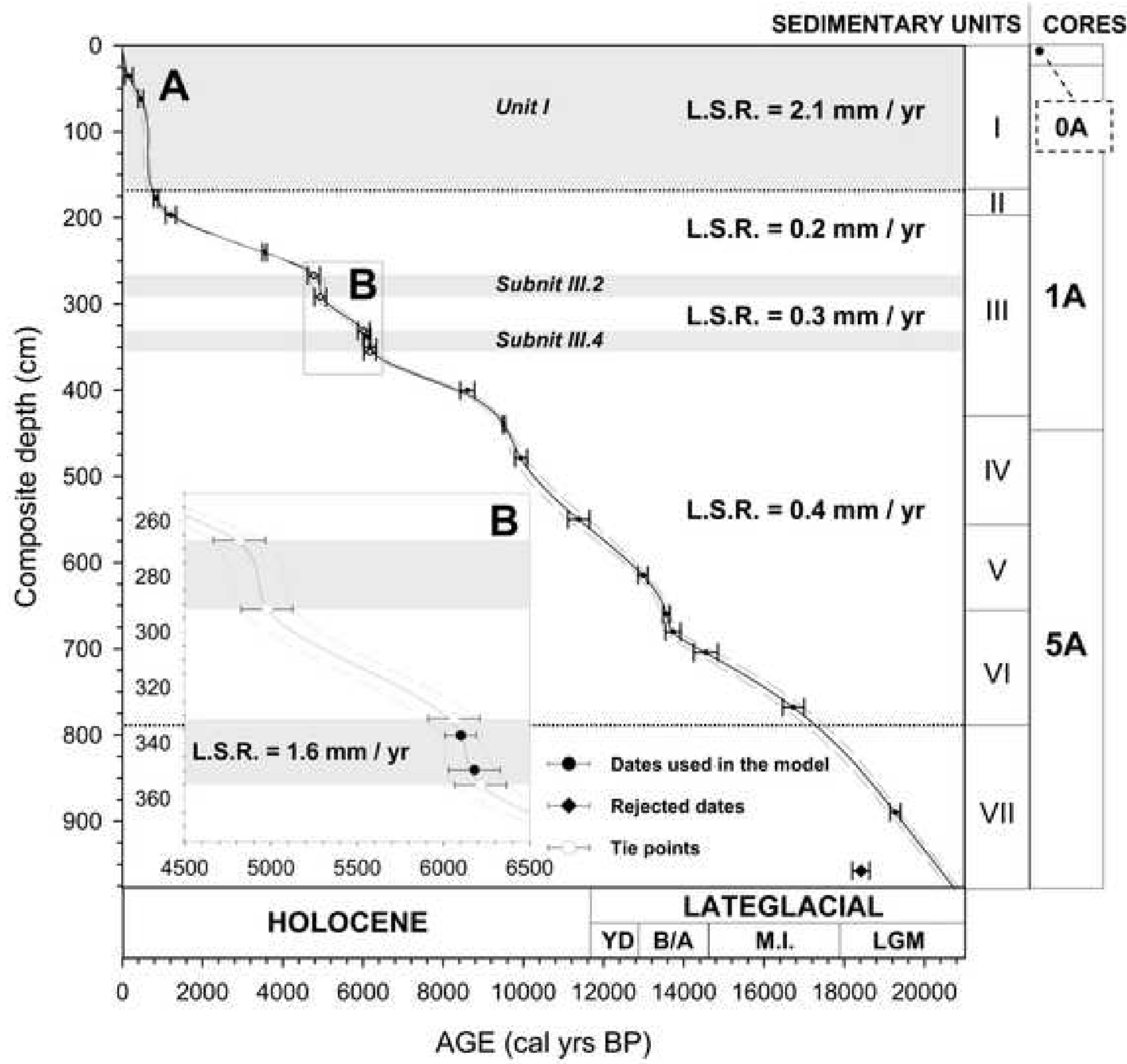


Age (cal yrs BP)

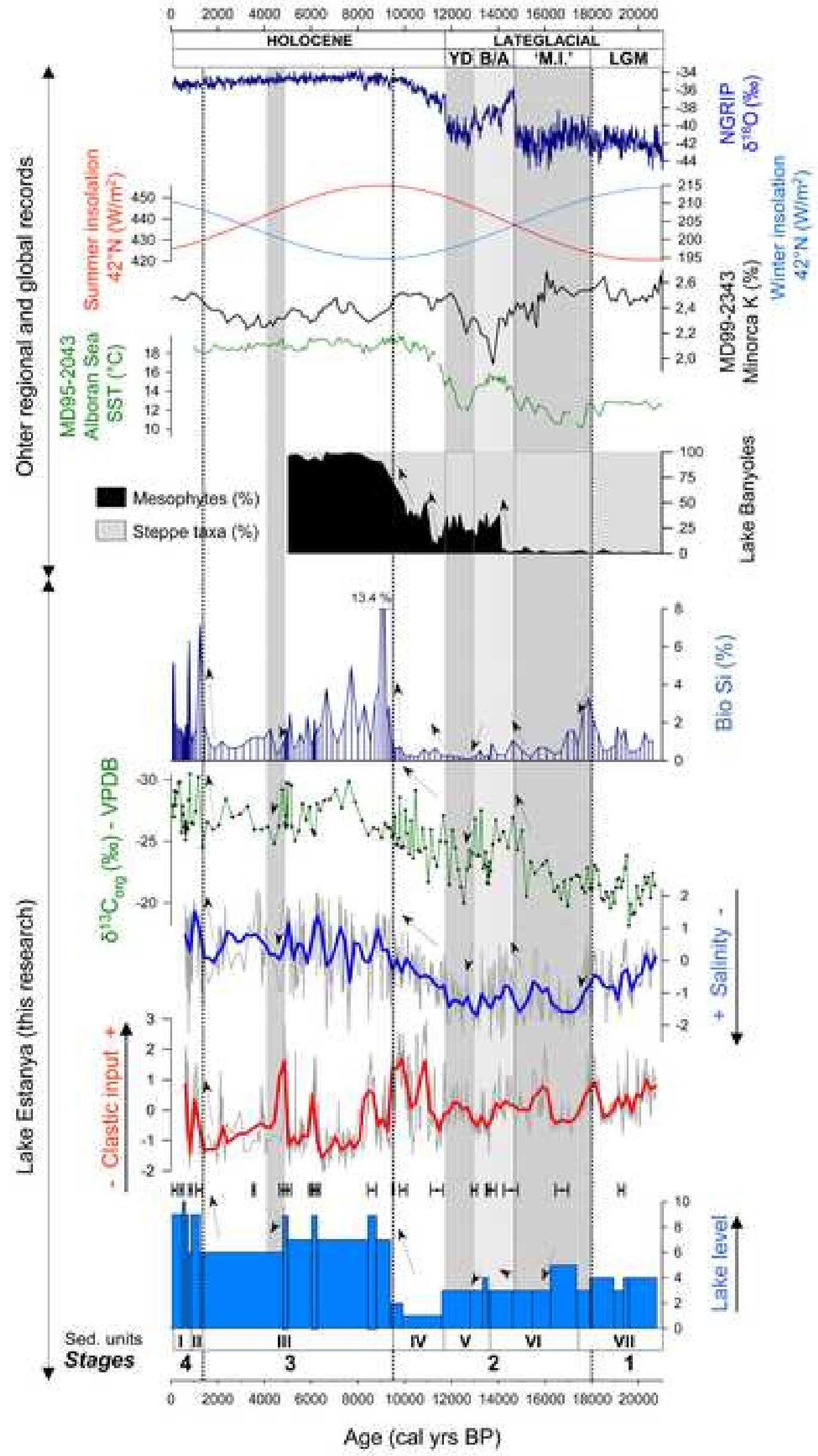

